\author{
Supporting Information
}

\title{
Intramolecular Hydrogen Bond Directed Distribution of Conformational Populations in Derivatives of $N^{\prime}$ - benzylidenebenzohydrazide
}

\author{
Neeru Arya, Sandeep Kumar Mishra and N. Suryaprakash* \\ NMR Research Centre and Solid State and Structural Chemistry Unit, Indian Institute of \\ Science, Bangalore 560012, India. \\ E-mail: nsp@iisc.ac.in; suryaprakash1703@gmail.com ; Fax: +91 8023601550; Tel: +91 \\ 8023607344; +91 80 22933300; +919845124802 (Cell)
}




\section{Table of Contents}

Figure S1: $400 \mathrm{MHz}{ }^{1} \mathrm{H}$ NMR spectrum of molecule 1 in the solvent $\mathrm{CDCl}_{3}$ at $298 \mathrm{~K}$. Figure S2: $400 \mathrm{MHz}{ }^{1} \mathrm{H}$ NMR spectrum of molecule 2 in the solvent $\mathrm{CDCl}_{3}$ at $298 \mathrm{~K}$. Figure S3: $400 \mathrm{MHz}{ }^{1} \mathrm{H}$ NMR spectrum of molecule 4 in the solvent $\mathrm{CDCl}_{3}$ at $298 \mathrm{~K}$. Figure S4: $400 \mathrm{MHz}{ }^{1} \mathrm{H}$ NMR spectrum of molecule 5 in the solvent $\mathrm{CDCl}_{3}$ at $298 \mathrm{~K}$. Figure S5: $400 \mathrm{MHz}{ }^{1} \mathrm{H}$ NMR spectrum of molecule 6 in the solvent $\mathrm{CDCl}_{3}$ at $298 \mathrm{~K}$.

Figure S6: $400 \mathrm{MHz}{ }^{1} \mathrm{H}$ NMR spectrum for 1:1 ratio of molecules 3 and $\mathbf{5}$ in the solvent $\mathrm{CDCl}_{3}$ at $298 \mathrm{~K}$.

Figure S7: a) $400 \mathrm{MHz}{ }^{1} \mathrm{H}$ DOSY spectrum of $1: 1$ ratio of molecules 3 and 5; b) $500 \mathrm{MHz}$ DOSY spectrum of 1:1:1 ratio of molecules $\mathbf{2}, \mathbf{3}$ and $\mathbf{5}$ at $298 \mathrm{~K}$ in the solvent $\mathrm{CDCl}_{3}$.

Figure S8: $400 \mathrm{MHz} 1 \mathrm{D}$ NOE spectra of molecule 6 in the solvent $\mathrm{CDCl}_{3}$, at $298 \mathrm{~K}$.

Figure S9: $400 \mathrm{MHz}{ }^{1} \mathrm{H}-{ }^{1} \mathrm{H}$ 2D EXSY spectrum of molecule 3 in the solvent $\mathrm{CDCl}_{3}$ at $298 \mathrm{~K}$.

Figure S10: $800 \mathrm{MHz} 2 \mathrm{D}^{1} \mathrm{H}-{ }^{1} \mathrm{H}$ NOESY spectrum of molecule 1 in the solvent $\mathrm{CDCl}_{3}$ at 298 $\mathrm{K}$.

Figure S11: $800 \mathrm{MHz} 2 \mathrm{D}^{1} \mathrm{H}-{ }^{1} \mathrm{H}$ NOESY spectrum of molecule 5 in the solvent $\mathrm{CDCl}_{3}$ at 298 $\mathrm{K}$.

Figure $\mathrm{S} 12.400 \mathrm{MHz}{ }^{1} \mathrm{H}$ NMR spectrum of molecule 1 in the solvent DMSO at $298 \mathrm{~K}$.

Figure S13: $400 \mathrm{MHz}{ }^{1} \mathrm{H}$ NMR spectrum of molecule 2 in the solvent DMSO at $298 \mathrm{~K}$.

Figure S14: $400 \mathrm{MHz}{ }^{1} \mathrm{H}$ NMR spectrum of molecule 3 in the solvent DMSO at 298K.

Figure S15: $400 \mathrm{MHz}{ }^{1} \mathrm{H}$ NMR spectrum of molecule 5 in the solvent DMSO at $298 \mathrm{~K}$.

Figure S16: $400 \mathrm{MHz}{ }^{1} \mathrm{H}$ NMR spectrum of molecule 6 in the solvent DMSO at $298 \mathrm{~K}$.

Figure S17. $400 \mathrm{MHz}{ }^{1} \mathrm{H}-\mathrm{NMR}$ spectra of the selected NH regions of molecules 3 at different temperatures from $298 \mathrm{~K}$ to $220 \mathrm{~K}$ (from bottom trace to top trace) in $\mathrm{CDCl}_{3}$ solvent.

Figure S18. $400 \mathrm{MHz}{ }^{13} \mathrm{C}$ NMR spectrum of molecule 2 in the solvent $\mathrm{CDCl}_{3}$ at $298 \mathrm{~K}$.

Figure S19. $400 \mathrm{MHz}{ }^{13} \mathrm{C}$ NMR spectrum of molecule 3 in the solvent $\mathrm{CDCl}_{3}$ at $298 \mathrm{~K}$.

Figure S20. $400 \mathrm{MHz}{ }^{13} \mathrm{C}$ NMR spectrum of molecule 5 in the solvent $\mathrm{CDCl}_{3}$ at $298 \mathrm{~K}$.

Figure S21. $400 \mathrm{MHz}{ }^{13} \mathrm{C}$ NMR spectrum of molecule 6 in the solvent $\mathrm{CDCl}_{3}$ at $298 \mathrm{~K}$.

S16: Theoretical computations (Figure S22-S24)

S21: Experimental

S23: References 


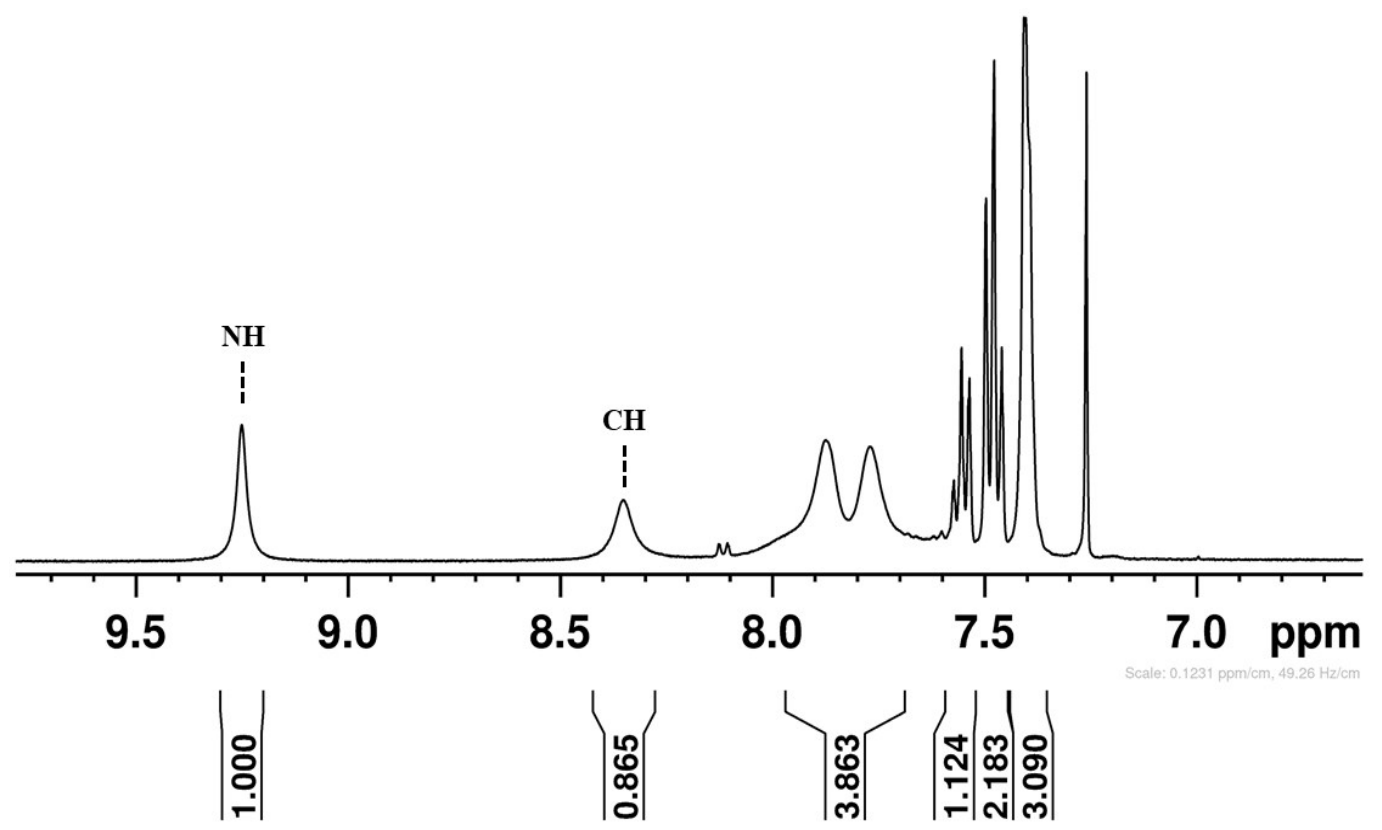

Figure S1. $400 \mathrm{MHz}{ }^{1} \mathrm{H}$ NMR spectrum of molecule 1 in the solvent $\mathrm{CDCl}_{3}$ at $298 \mathrm{~K}$. $\mathrm{NH}$ imide and $\mathrm{CH}$ vinyl proton peaks are identified.

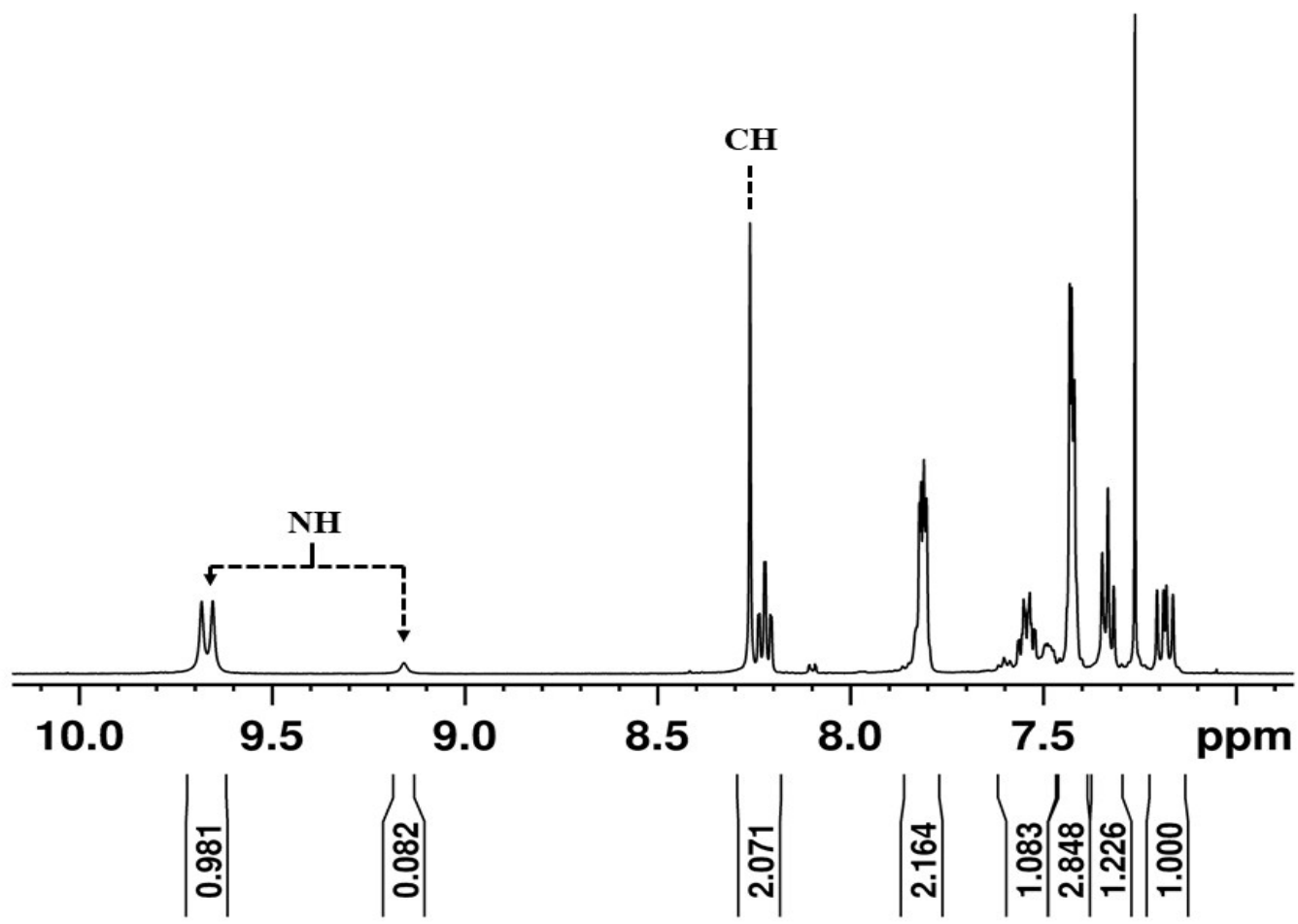

Figure S2. $400 \mathrm{MHz}{ }^{1} \mathrm{H}$ NMR spectrum of molecule 2 in the solvent $\mathrm{CDCl}_{3}$ at $298 \mathrm{~K}$. NH imide and $\mathrm{CH}$ vinyl proton peaks are identified. 


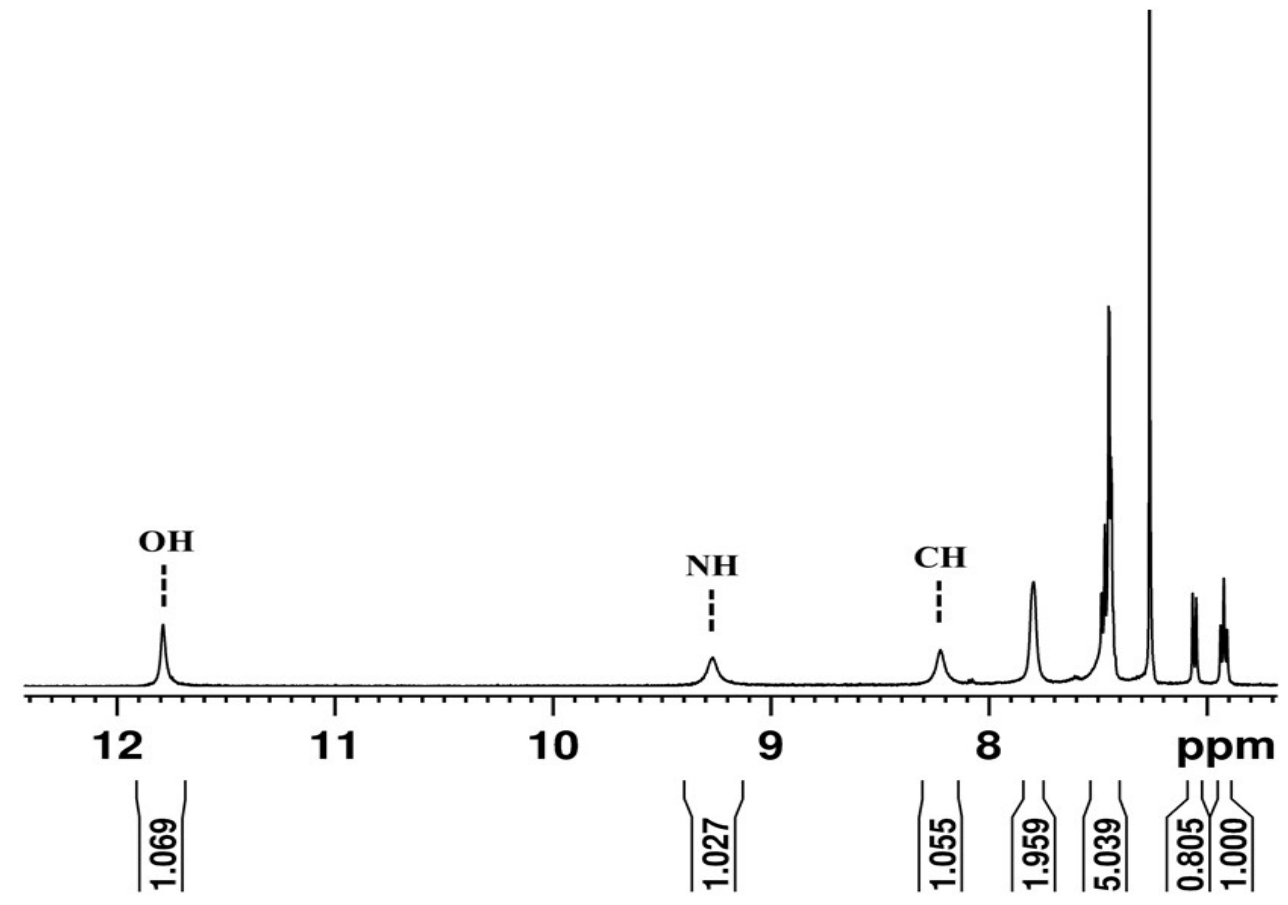

Figure S3. $400 \mathrm{MHz}{ }^{1} \mathrm{H}$ NMR spectrum of molecule 4 in the solvent $\mathrm{CDCl}_{3}$ at $298 \mathrm{~K}$. $\mathrm{NH}$ imide and $\mathrm{CH}$ vinyl proton peaks are identified.

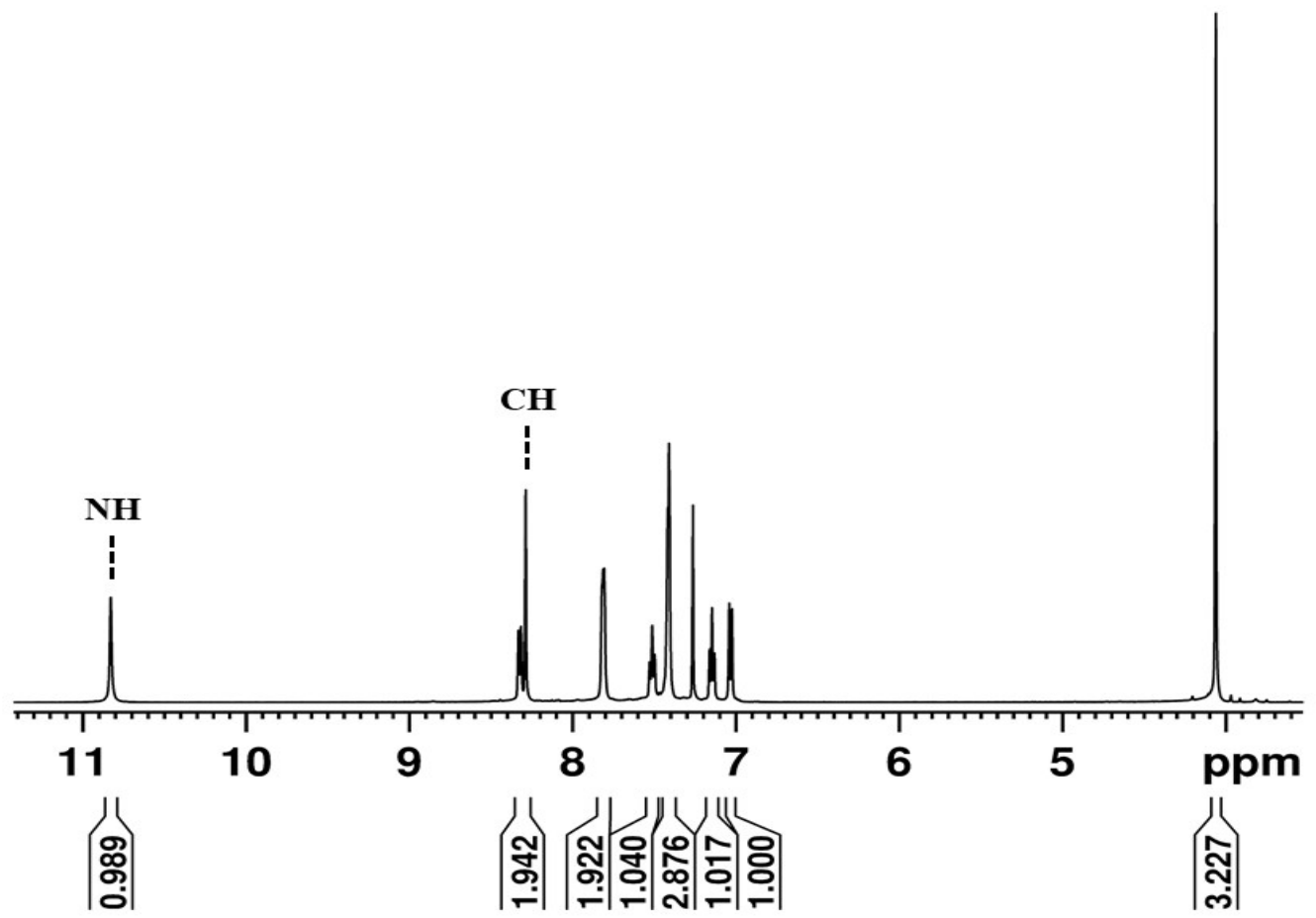

Figure S4. $400 \mathrm{MHz}{ }^{1} \mathrm{H}$ NMR spectrum of molecule 5 in the solvent $\mathrm{CDCl}_{3}$ at $298 \mathrm{~K}$. $\mathrm{NH}$ imide and $\mathrm{CH}$ vinyl proton peaks are identified. 


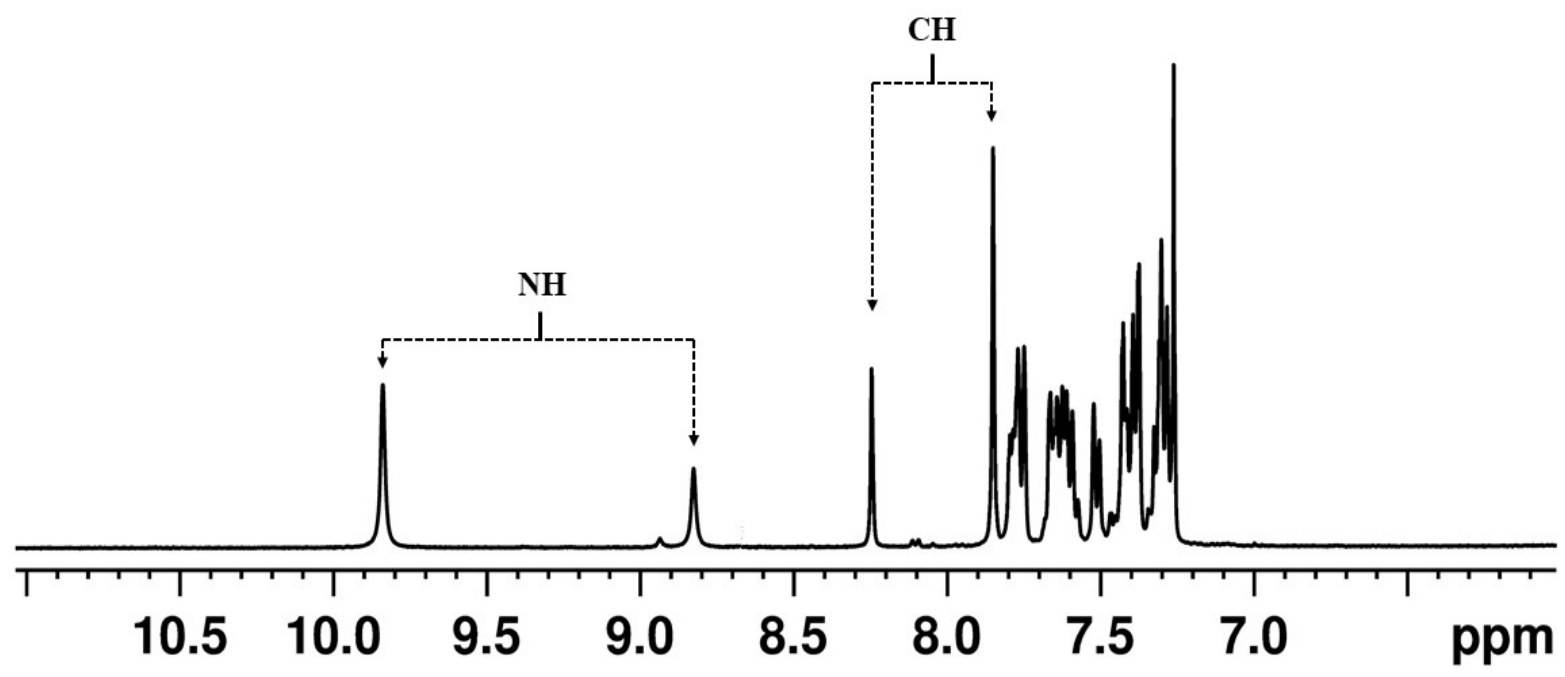

Figure S5. $400 \mathrm{MHz}{ }^{1} \mathrm{H}$ NMR spectrum of molecule 6 in the solvent $\mathrm{CDCl}_{3}$ at $298 \mathrm{~K}$. NH imide and $\mathrm{CH}$ vinyl proton peaks are identified. Because of severe overlap of signals, the integral values are likely to be imprecise and hence not reported.

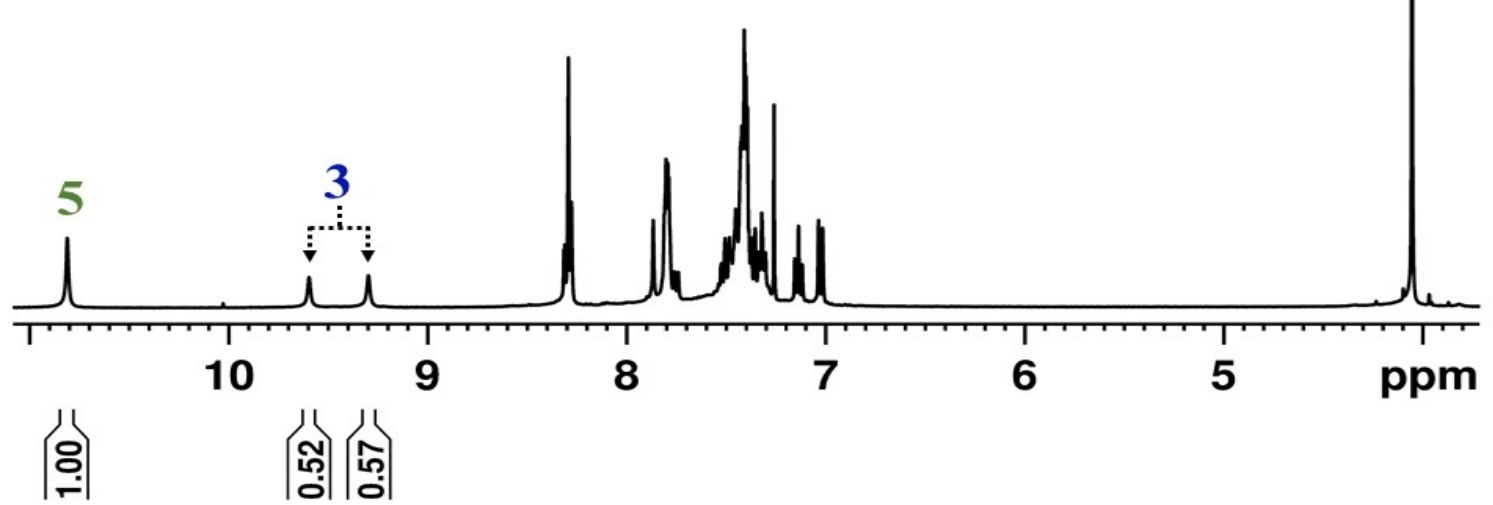

Figure S6. $400 \mathrm{MHz}{ }^{1} \mathrm{H}$ NMR spectrum for 1:1 ratio of molecules 3 and $\mathbf{5}$ in the solvent $\mathrm{CDCl}_{3}$ at $298 \mathrm{~K}$. Peaks marked 3 and 5 are the $\mathrm{NH}$ proton peaks for molecules $\mathbf{3}$ and $\mathbf{5}$ respectively. From the visual inspection, it is evident that the NH peak of molecule $\mathbf{3}$ appears as two peaks with nearly half the intensities of $\mathrm{NH}$ peak of molecule 5. However, the $\mathrm{CH}$ peaks cannot be identified due to severe signal overlap. 

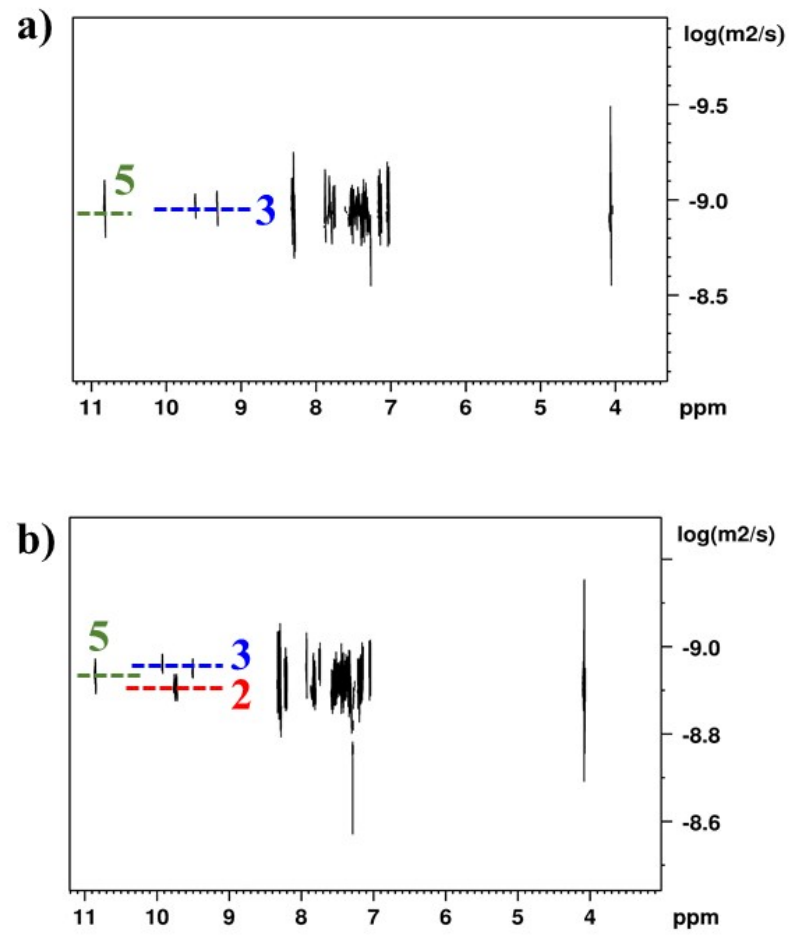

Figure S7. a) $400 \mathrm{MHz}{ }^{1} \mathrm{H}$ DOSY spectrum of 1:1 ratio of molecules 3 and 5; b) $500 \mathrm{MHz}$ DOSY spectrum of 1:1:1 ratio of molecules $\mathbf{2}, \mathbf{3}$ and $\mathbf{5}$ at $298 \mathrm{~K}$ in the solvent $\mathrm{CDCl}_{3}$.

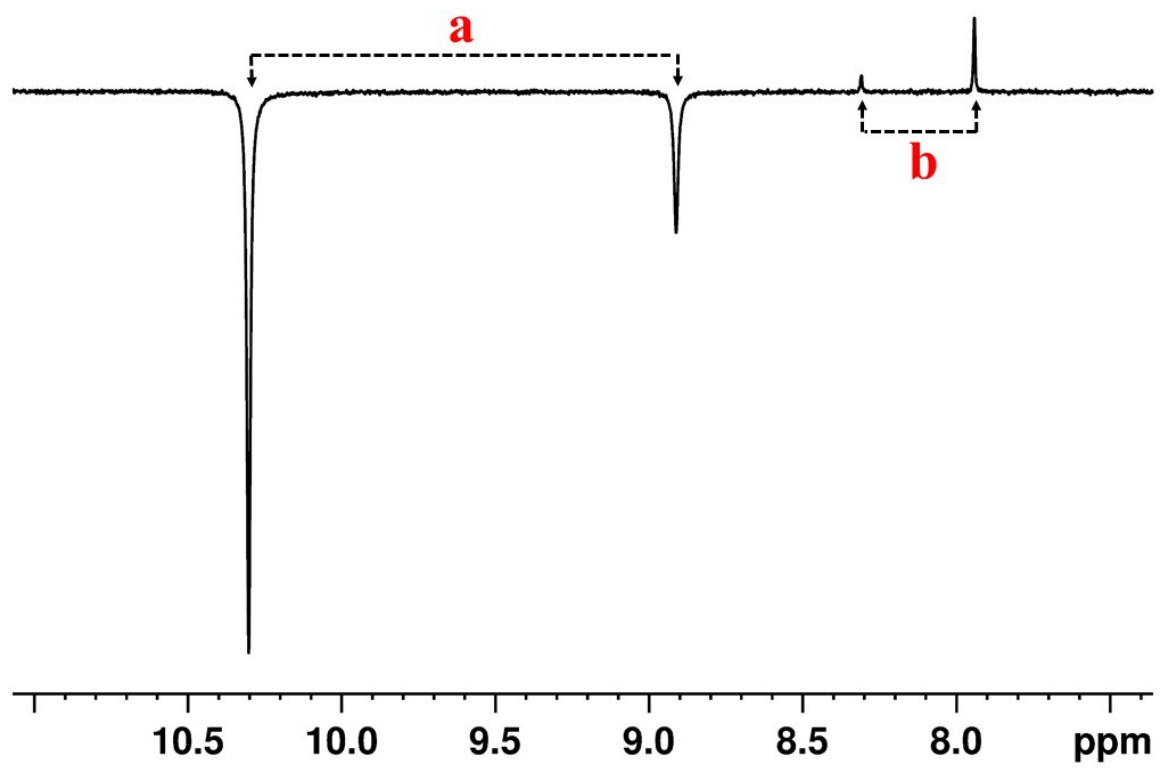

Figure S8. $400 \mathrm{MHz}$ 1D difference NOE spectrum of molecule 6 in the solvent $\mathrm{CDCl}_{3}$, at $298 \mathrm{~K}$ where the proton was selectively excited at $10.3 \mathrm{ppm}$. NH imide and $\mathrm{CH}$ vinyl proton peaks are identified by alphabets a and b respectively. 


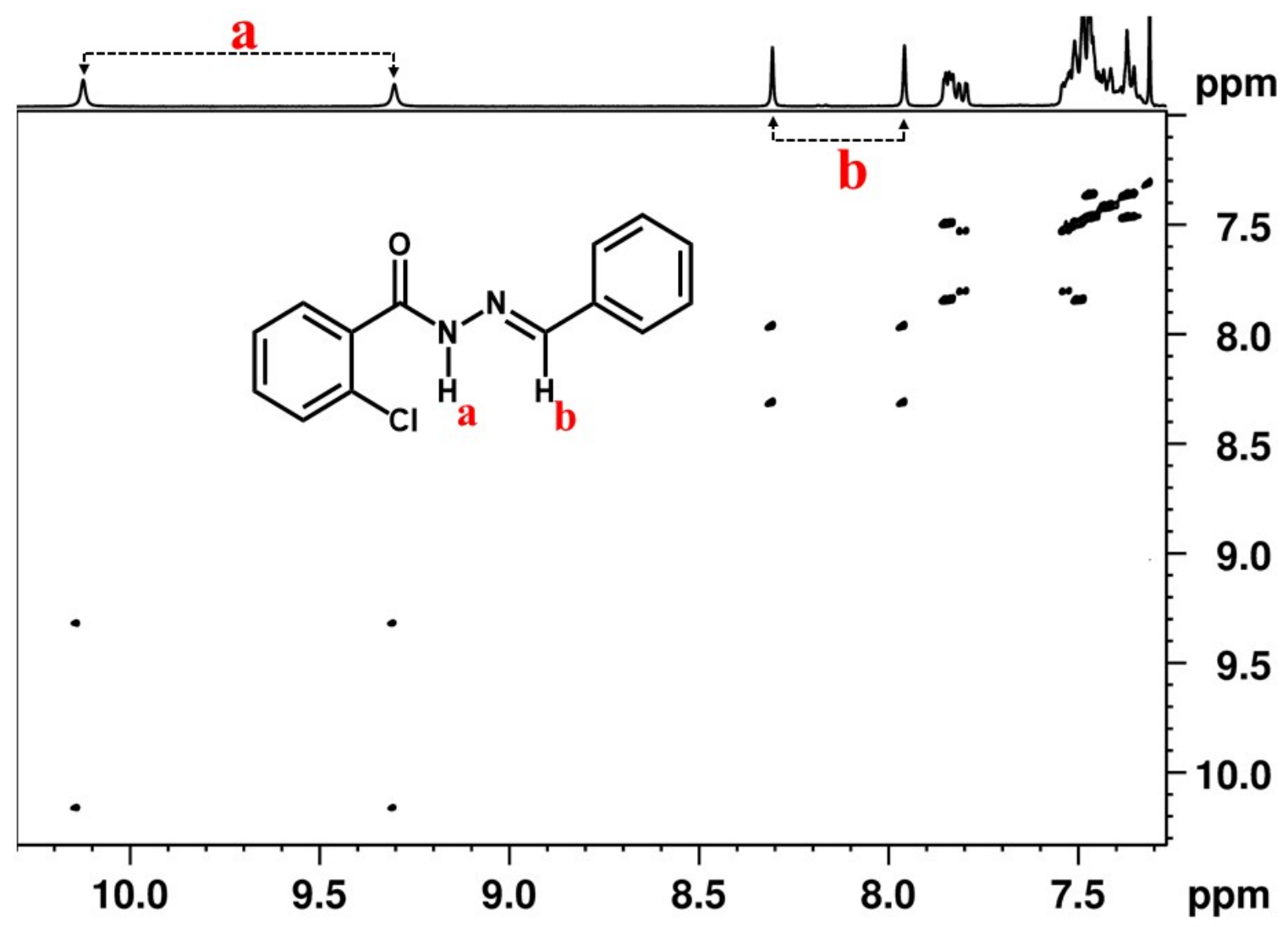

Figure S9. $400 \mathrm{MHz}{ }^{1} \mathrm{H}-{ }^{1} \mathrm{H}$ 2D-EXSY spectrum of molecule 3 in the solvent $\mathrm{CDCl}_{3}$ at 298 $\mathrm{K}$. NH imide and $\mathrm{CH}$ vinyl proton peaks are identified by alphabets a and $\mathrm{b}$ respectively. 


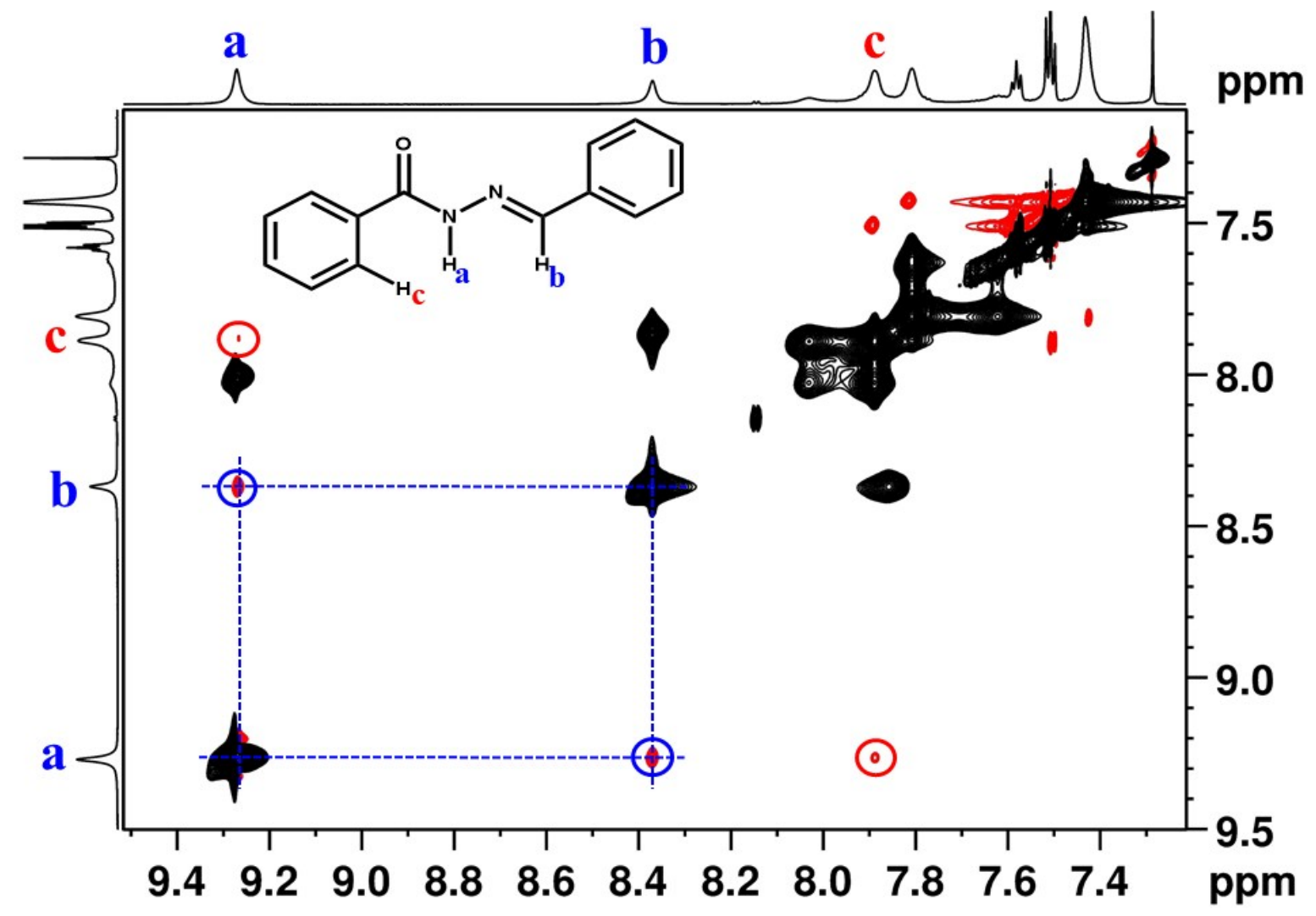

Figure S10: $800 \mathrm{MHz} 2 \mathrm{D}{ }^{1} \mathrm{H}_{-}{ }^{1} \mathrm{H}$ NOESY spectrum of molecule $\mathbf{1}$ in the solvent $\mathrm{CDCl}_{3}$ at $298 \mathrm{~K}$. NH imide and $\mathrm{CH}$ vinyl proton peaks are identified by alphabets a and b respectively. The cross peaks between these protons (identified by blue circle) confirms that the molecules exist as $E$ isomers with respect to $\mathrm{C}=\mathrm{N}$ bond. And the cross peaks between aromatic proton $\mathrm{H}_{\mathrm{c}}$ and imide $\mathrm{NH}$ proton $\mathrm{H}_{\mathrm{a}}$ (identified by red circle) confirms that the molecules exist as trans, $E_{\mathrm{C}-\mathrm{N}}$ conformer 


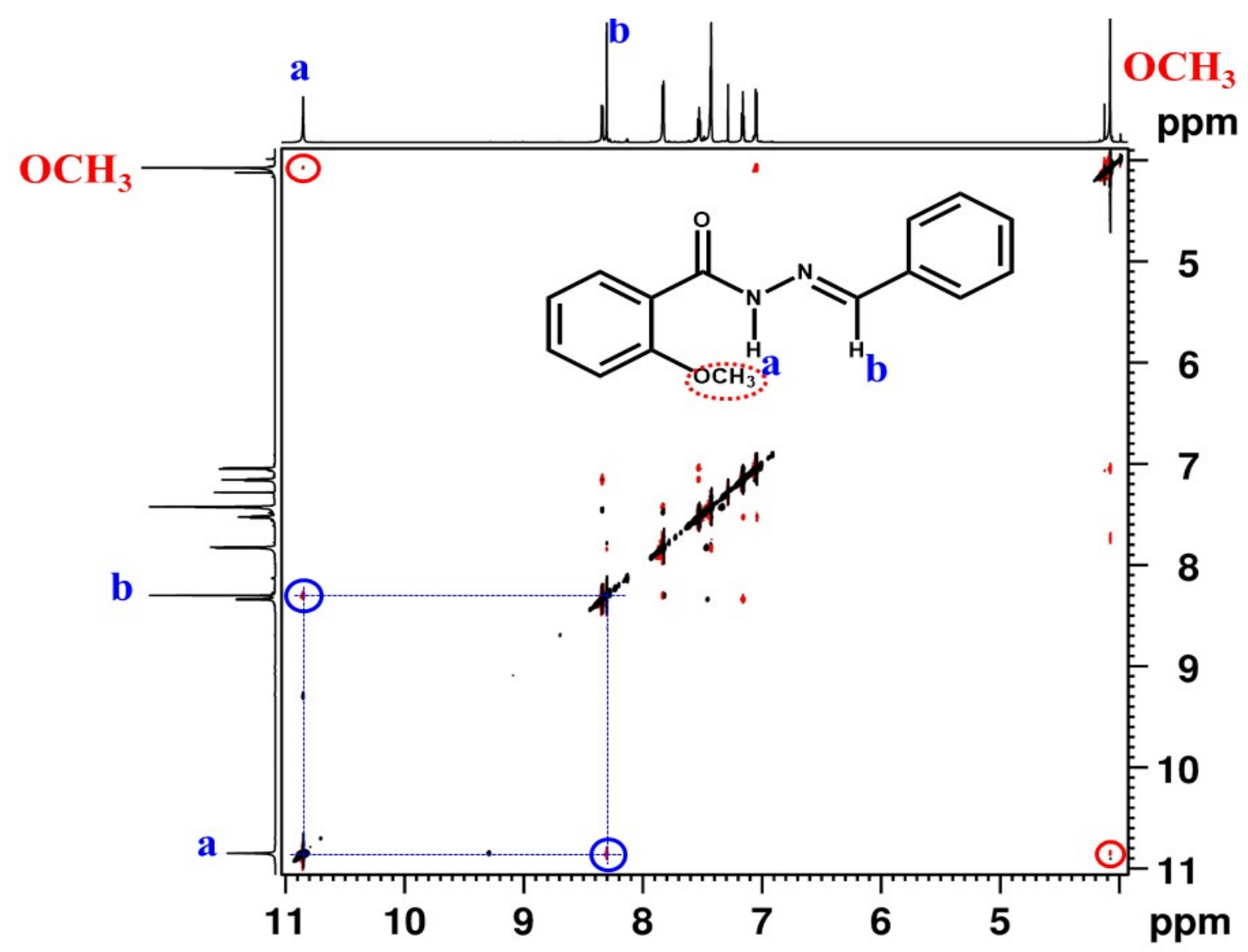

Figure S11: $800 \mathrm{MHz} 2 \mathrm{D}{ }^{1} \mathrm{H}-{ }^{1} \mathrm{H}$ NOESY spectrum of molecule 5 in the solvent $\mathrm{CDCl}_{3}$ at $298 \mathrm{~K}$. NH imide and $\mathrm{CH}$ vinyl proton peaks are identified by alphabets a and b respectively. The cross peaks between these protons (identified by blue circle) confirms that the molecules exist as $E$ isomers with respect to $\mathrm{C}=\mathrm{N}$ bond. And the cross peaks between methoxy substituent and imide $\mathrm{NH}$ proton (identified by red circle) confirms that the molecules exist as trans, $E_{\mathrm{C}-\mathrm{N}}$ conformer. 


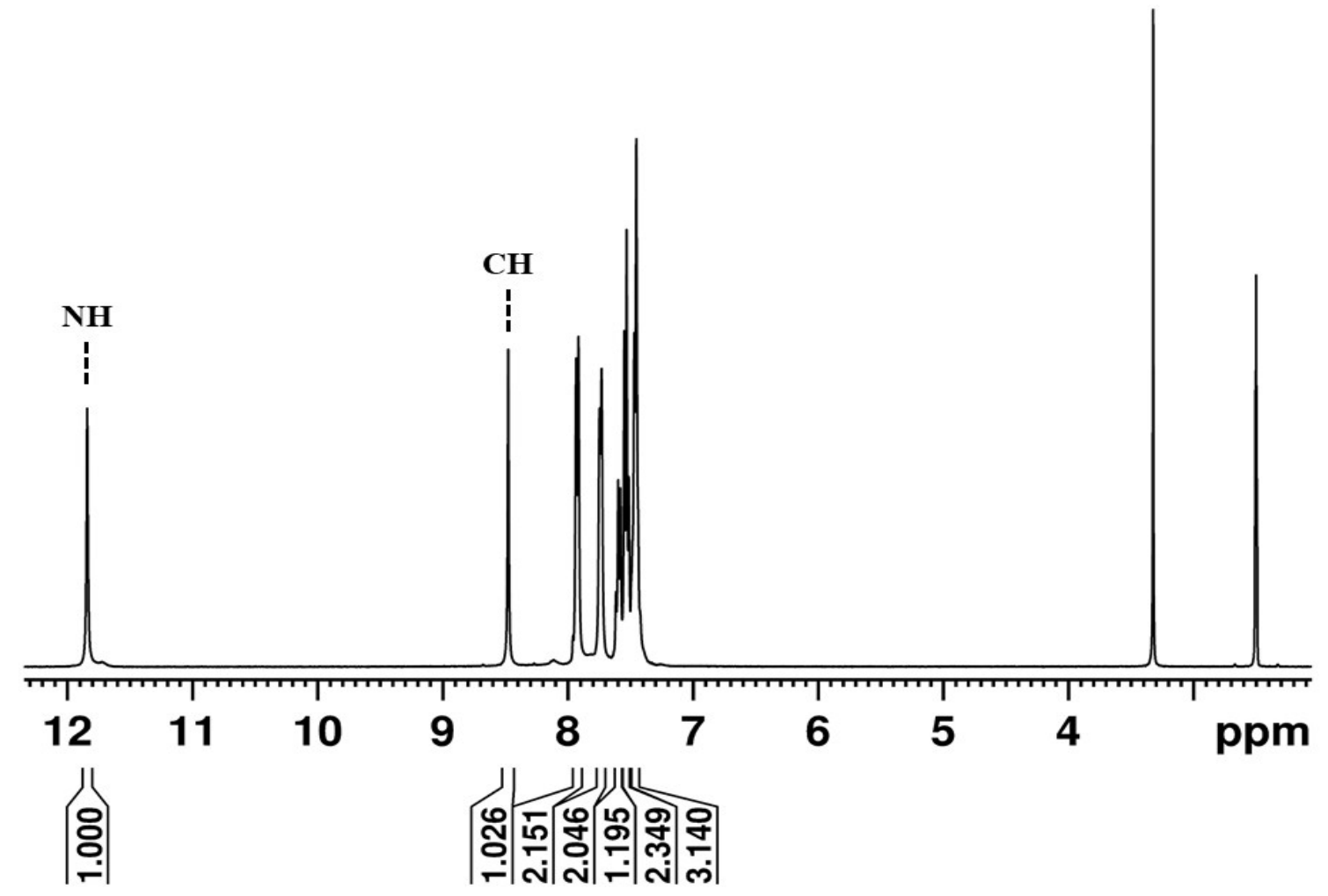

Figure S12. $400 \mathrm{MHz}{ }^{1} \mathrm{H}$ NMR spectrum of molecule 1 in the solvent DMSO at 298K. NH imide and $\mathrm{CH}$ vinyl proton peaks are identified. 


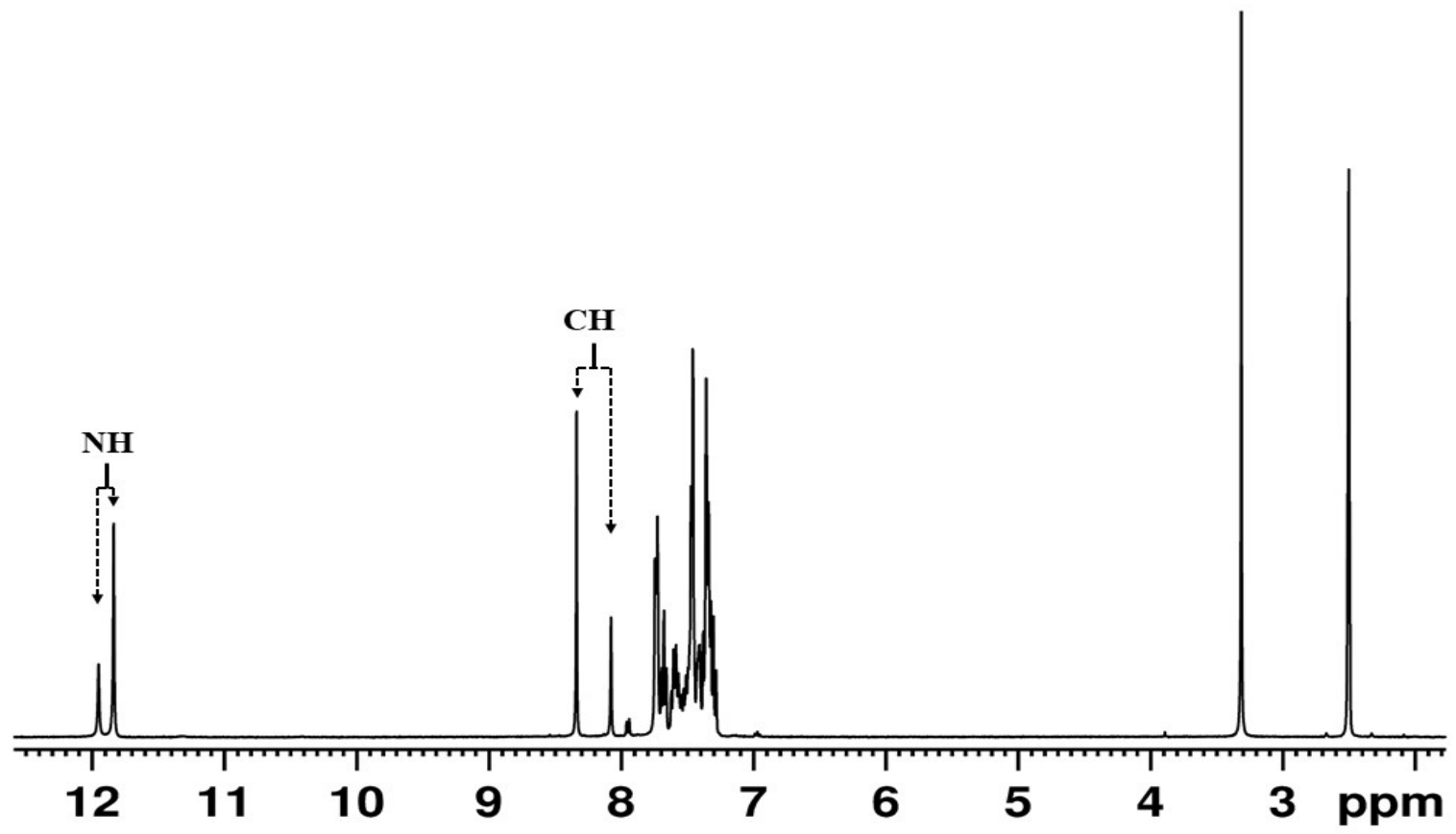

Figure S13. $400 \mathrm{MHz}{ }^{1} \mathrm{H}$ NMR spectrum of molecule 2 in the solvent DMSO at 298K. NH imide and $\mathrm{CH}$ vinyl proton peaks are identified. Because of severe overlap of signals, the integral values are likely to be imprecise and hence not reported.

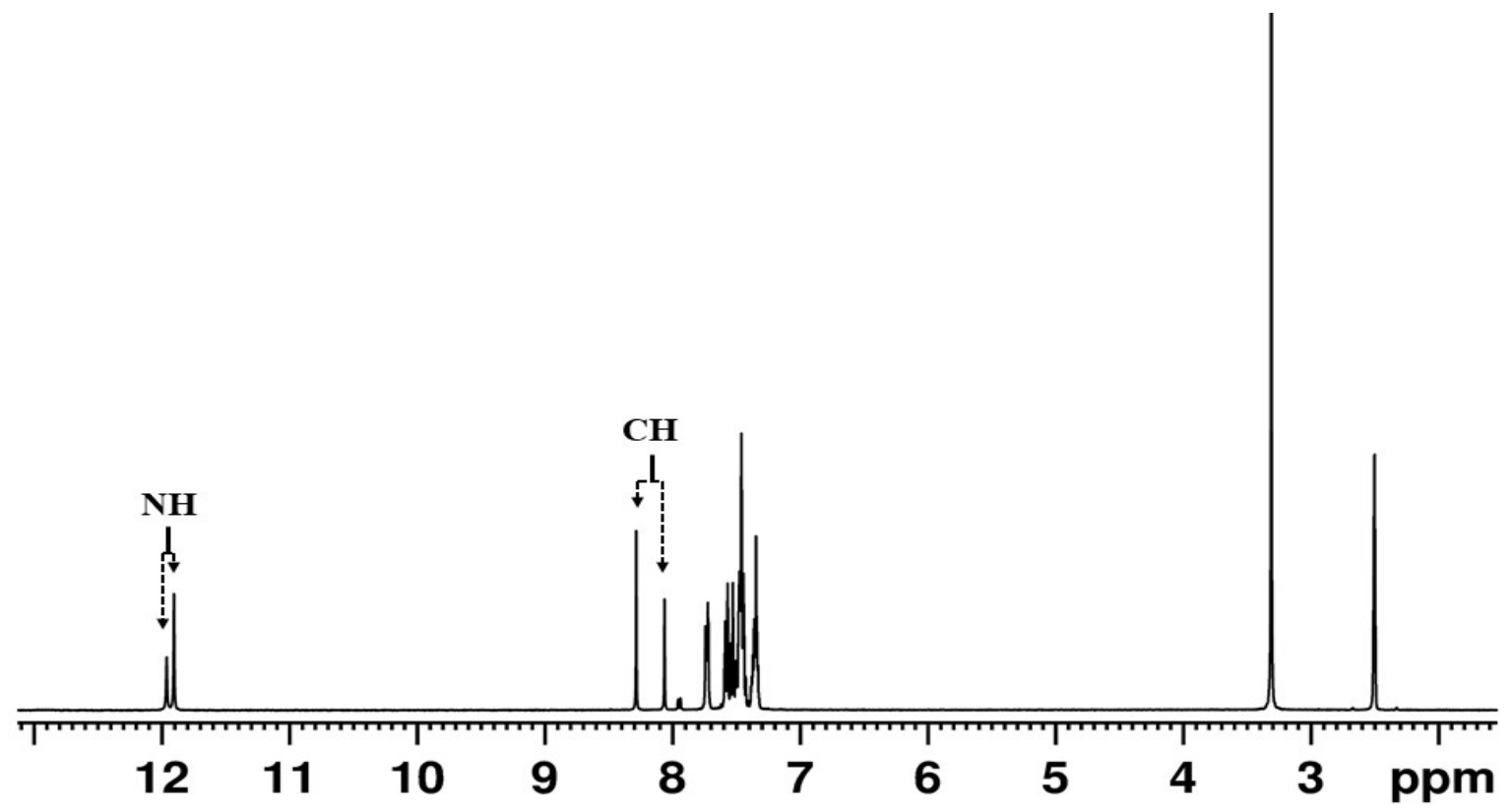

Figure S14. $400 \mathrm{MHz}{ }^{1} \mathrm{H}$ NMR spectrum of molecule 3 in the solvent DMSO at 298K. NH imide and $\mathrm{CH}$ vinyl proton peaks are identified. Because of severe overlap of signals, the integral values are likely to be imprecise and hence not reported. 


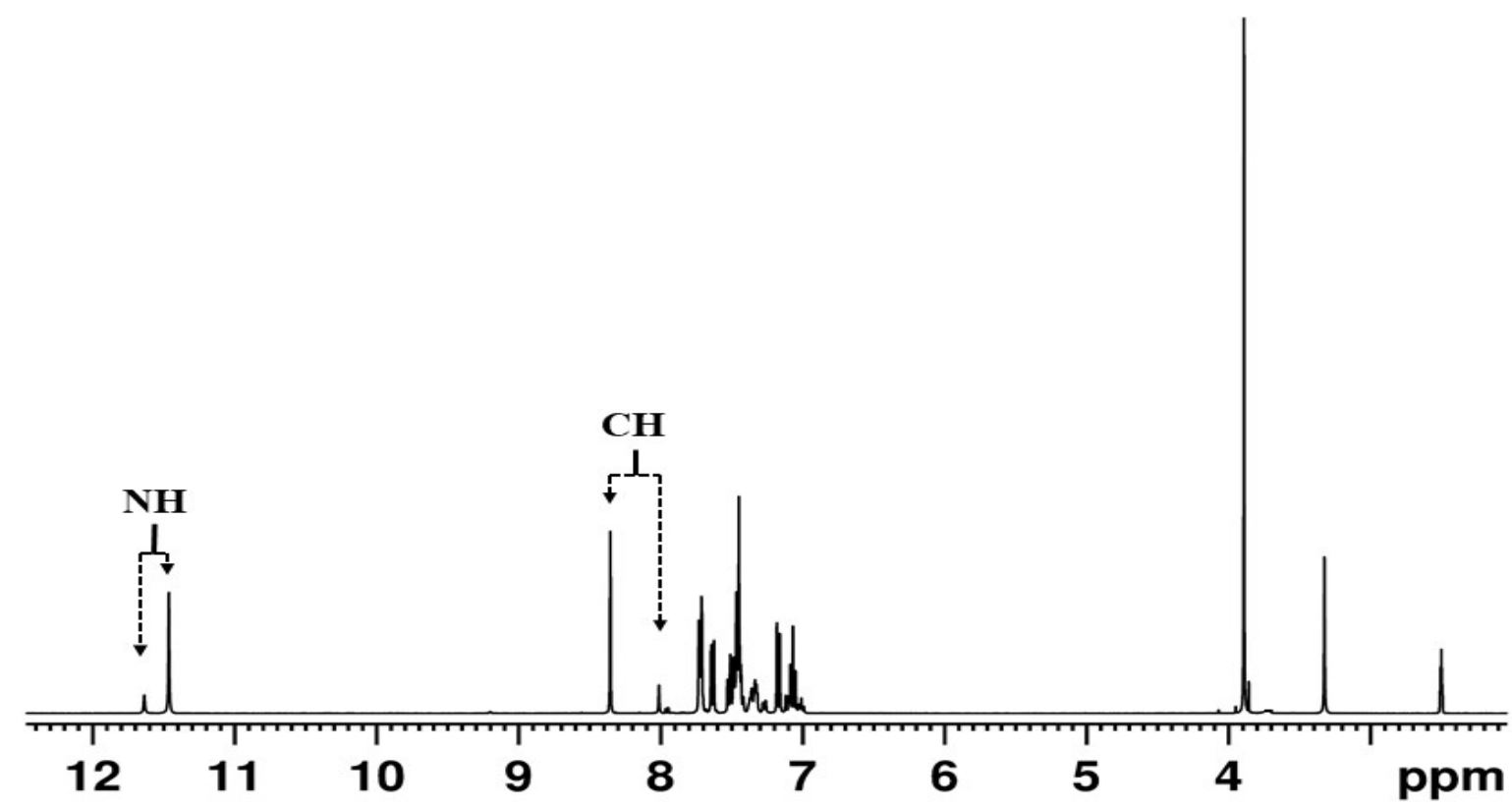

Figure S15. $400 \mathrm{MHz}{ }^{1} \mathrm{H}$ NMR spectrum of molecule 5 in the solvent DMSO at 298K. NH imide and $\mathrm{CH}$ vinyl proton peaks are identified. Because of severe overlap of signals, the integral values are likely to be imprecise and hence not reported.

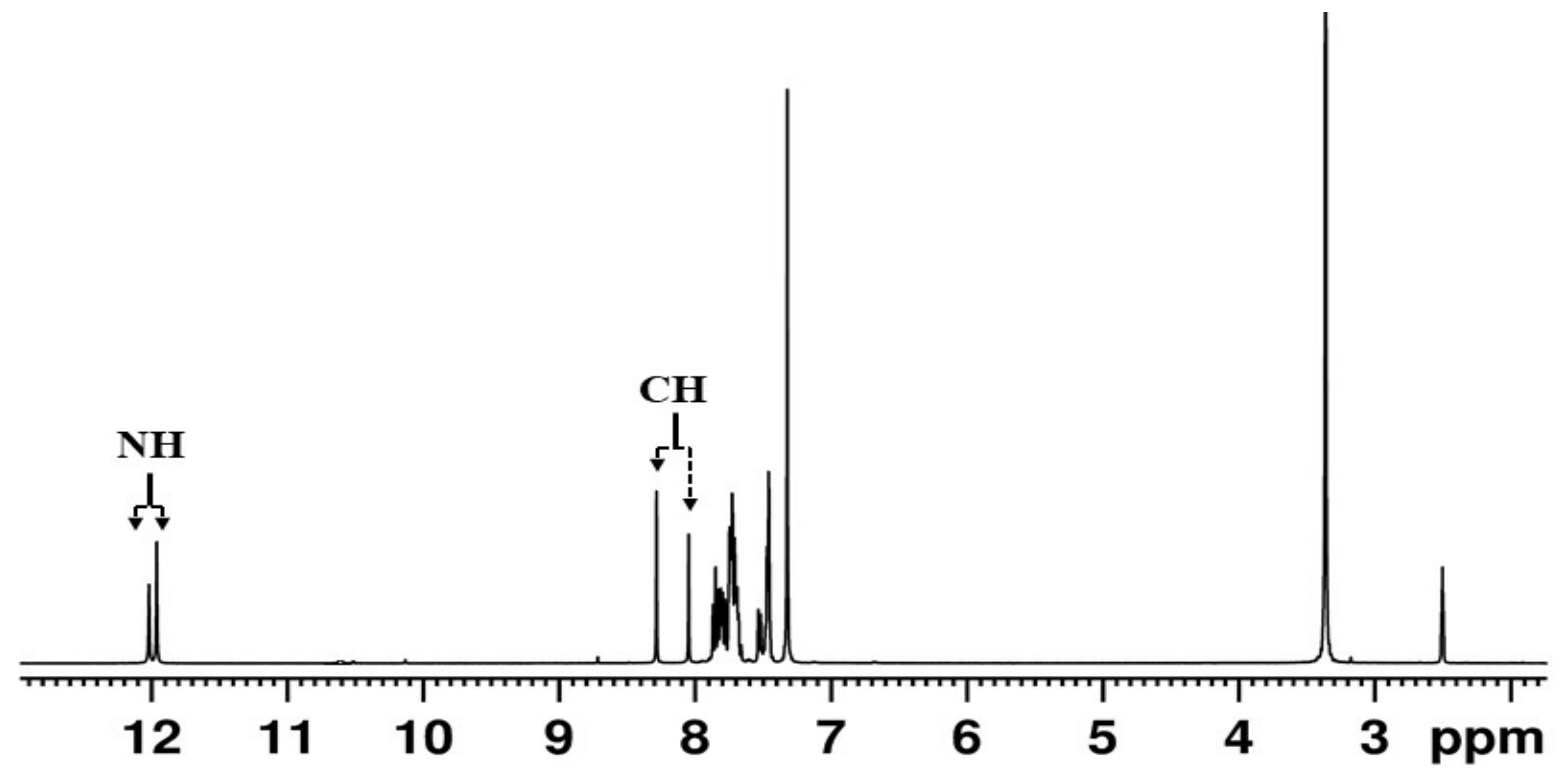

Figure S16. $400 \mathrm{MHz}{ }^{1} \mathrm{H}$ NMR spectrum of molecule 6 in the solvent DMSO at 298K. NH imide and $\mathrm{CH}$ vinyl proton peaks are identified. Because of severe overlap of signals, the integral values are likely to be imprecise and hence not reported. 


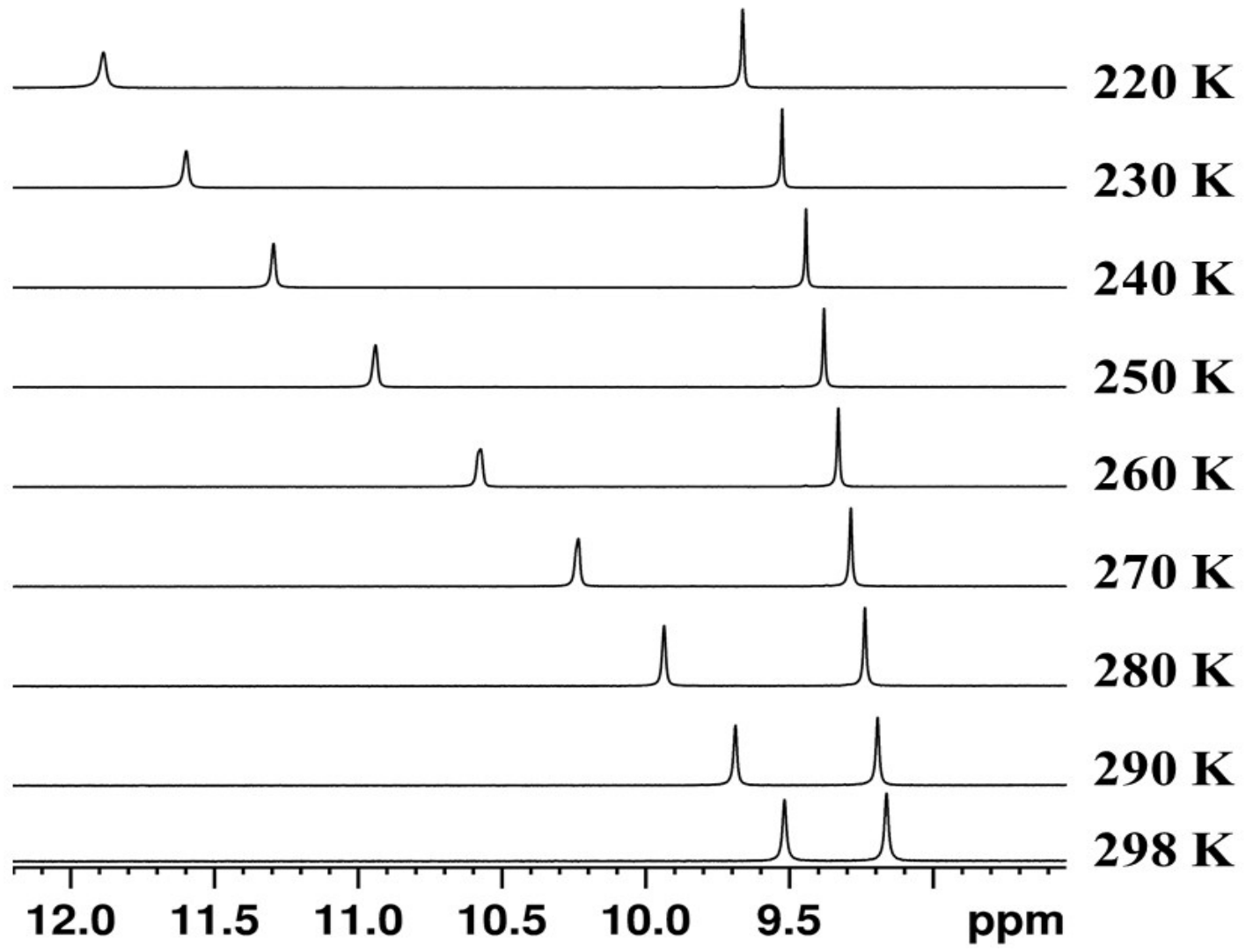

Figure S17. $400 \mathrm{MHz}{ }^{1} \mathrm{H}-\mathrm{NMR}$ spectra of the selected $\mathrm{NH}$ regions of molecules 3 at different temperatures from $298 \mathrm{~K}$ to $220 \mathrm{~K}$ (from bottom trace to top trace) in $\mathrm{CDCl}_{3}$ solvent. 


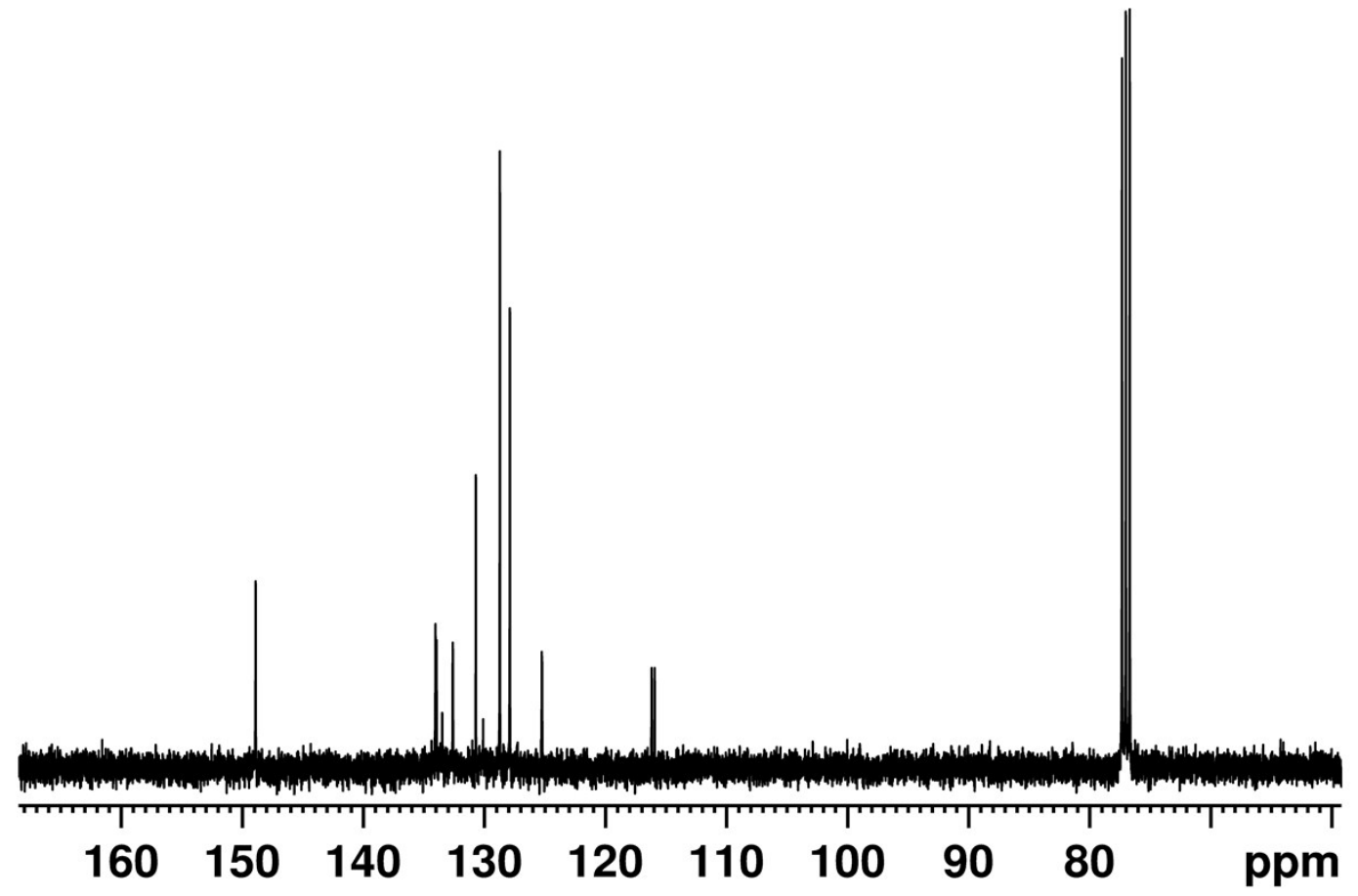

Figure S18. $400 \mathrm{MHz}{ }^{13} \mathrm{C}$ NMR spectrum of molecule 2 in the solvent $\mathrm{CDCl}_{3}$ at $298 \mathrm{~K}$.

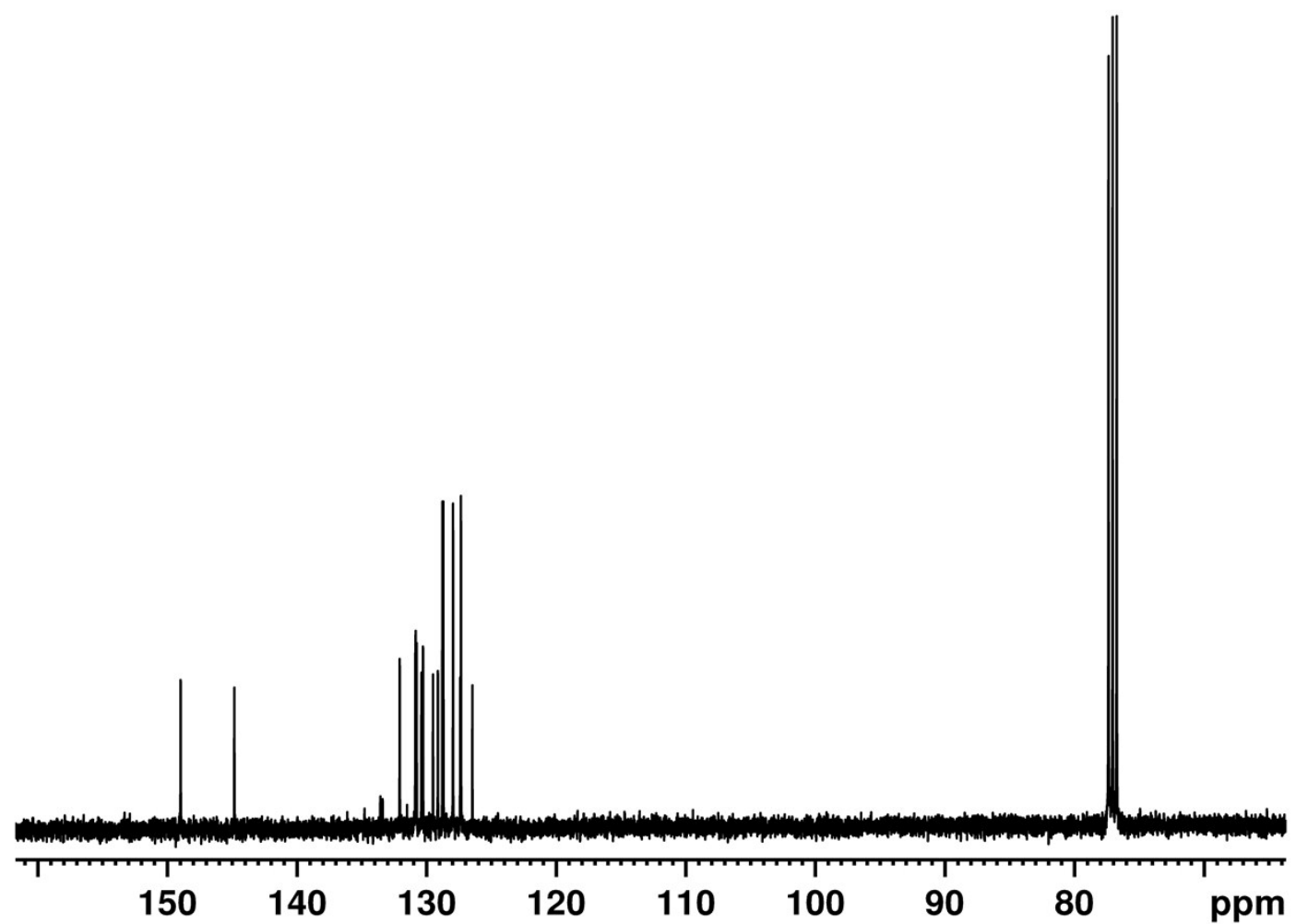

Figure S19. $400 \mathrm{MHz}{ }^{13} \mathrm{C}$ NMR spectrum of molecule 3 in the solvent $\mathrm{CDCl}_{3}$ at $298 \mathrm{~K}$. 


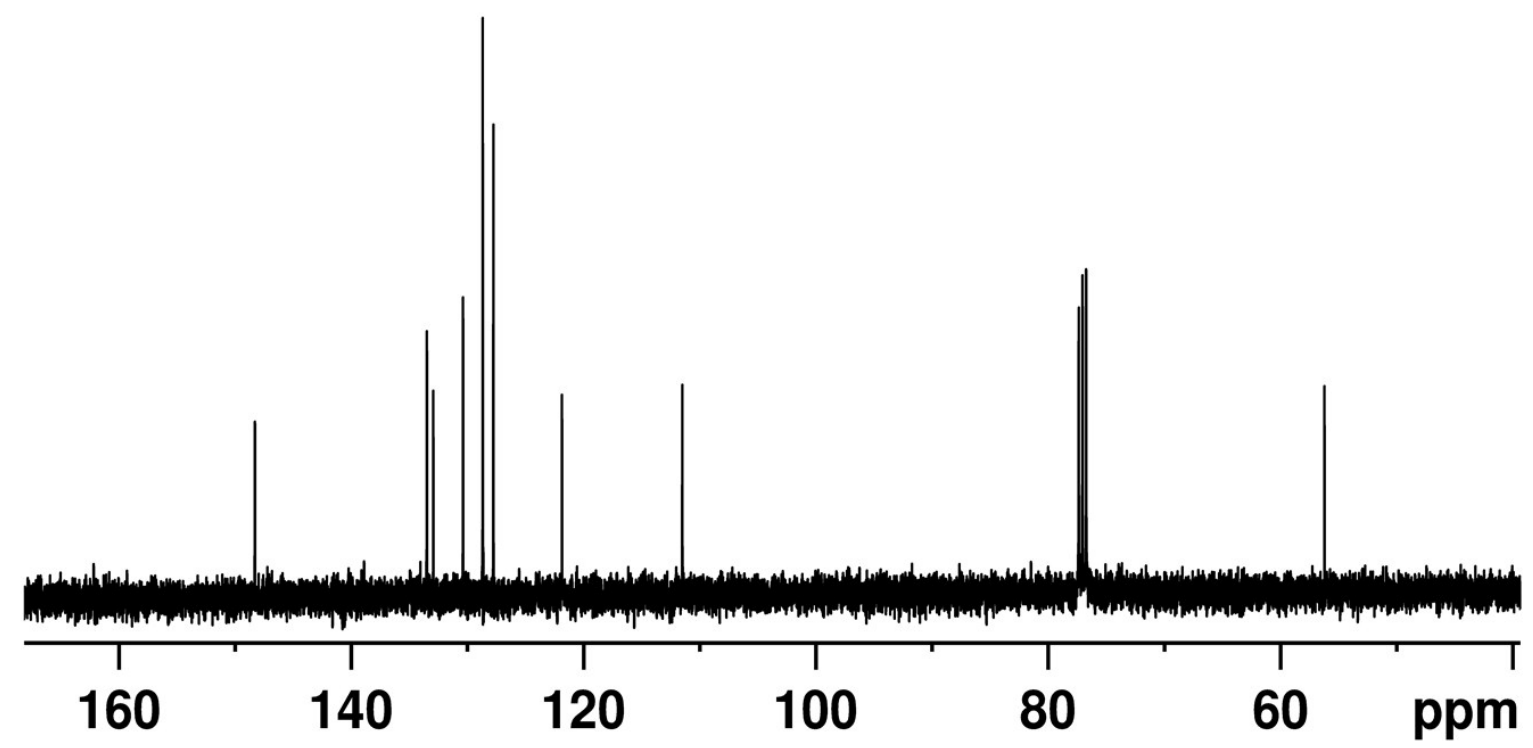

Figure S20. $400 \mathrm{MHz}{ }^{13} \mathrm{C}$ NMR spectrum of molecule 5 in the solvent $\mathrm{CDCl}_{3}$ at $298 \mathrm{~K}$.

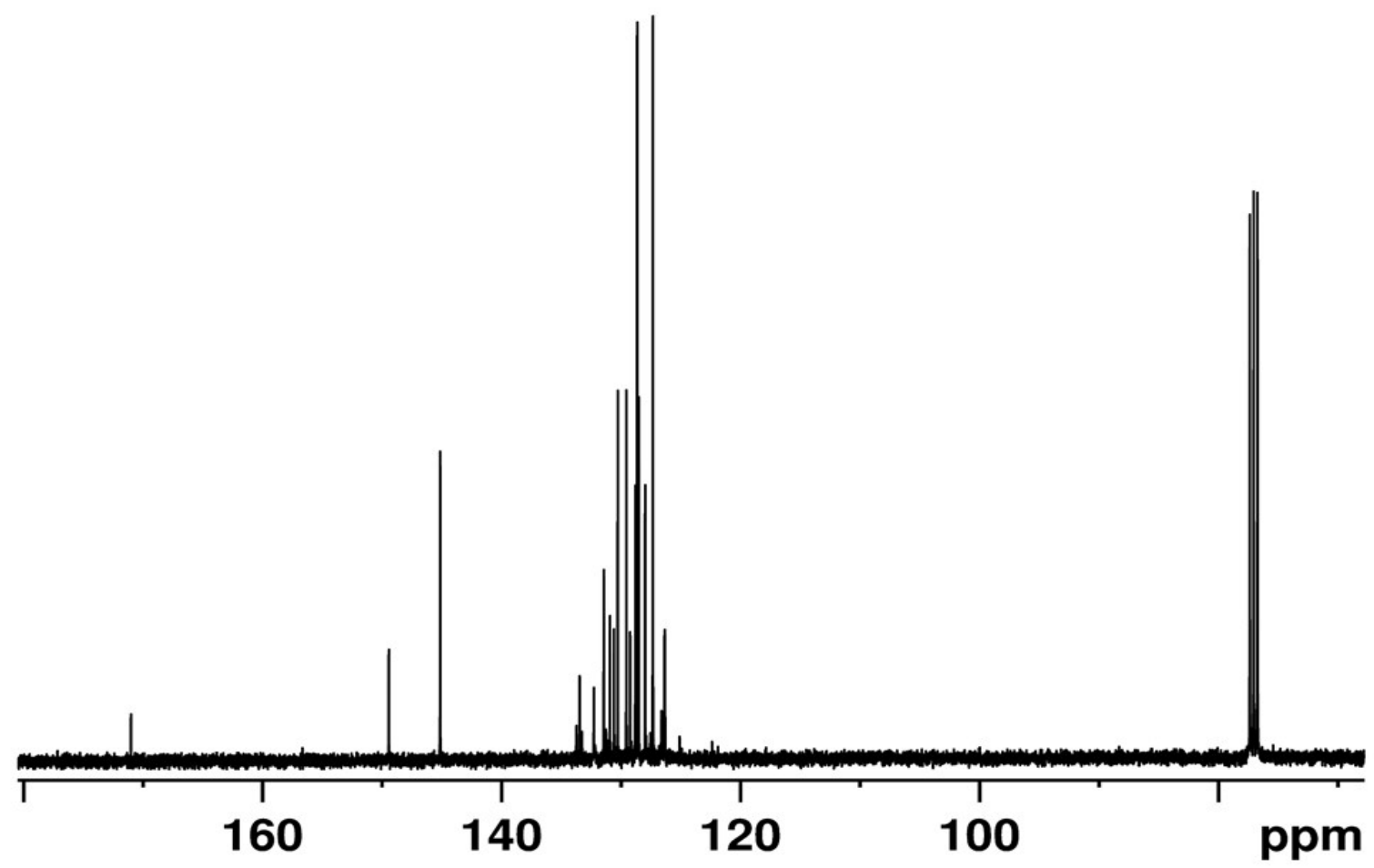

Figure S21. $400 \mathrm{MHz}{ }^{13} \mathrm{C}$ NMR spectrum of molecule 6 in the solvent $\mathrm{CDCl}_{3}$ at $298 \mathrm{~K}$.

\section{S15}




\section{Theoretical computations}

\section{QTAIM Studies}

Quantum theory of atoms in molecules (QTAIM) ${ }^{1-4}$ makes use of quantum observables electron density $\rho_{(\mathrm{r})}$ and energy density for HB determination. The presence of $(3,-1)$ critical point, commonly known as Bond Critical Point (BCP) in between the bond path joining two atoms indicates that the two atoms are hydrogen bonded. The BCPs and the bond paths of all the investigated molecules for both the conformers I and II are reported in Fig. S22. The sign of the Laplacian of electron density $\left(\Delta^{2} \rho_{(\mathrm{r})}\right)$ and the value of electron density $\left(\rho_{(\mathrm{r})}\right)$ at the BCPs are of great significance in determining the types and the strengths of HBs. Since there is no (X---N-H) intramolecular HB in conformer II, the magnitude of $\rho_{(\mathrm{r})}$ and the sign of $\Delta^{2} \rho_{(\mathrm{r})}$ for conformer I of molecules $\mathbf{2 ,} \mathbf{3}, \mathbf{5}$ and $\mathbf{6}$ are reported in Table S1.

a)<smiles>[X]c1ccccc1C(=O)N/N=C/c1ccccc1</smiles>

I trans, $E_{\mathrm{C}-\mathrm{N}}$

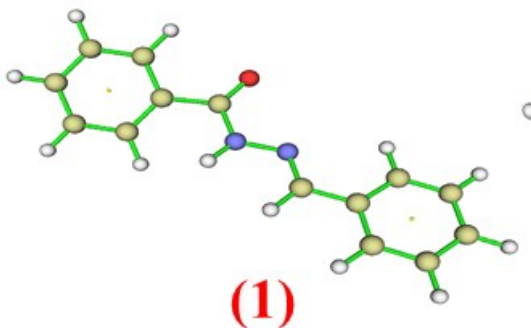

(1)

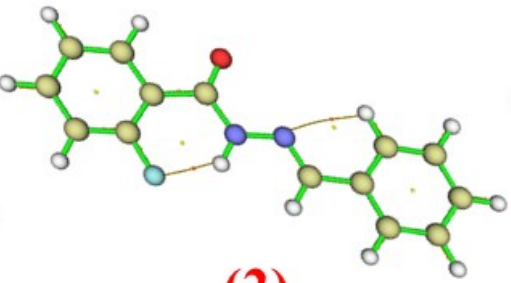

(2)

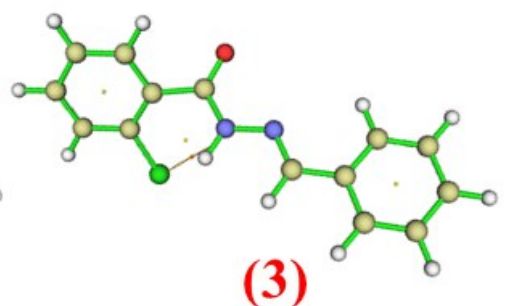

(3)

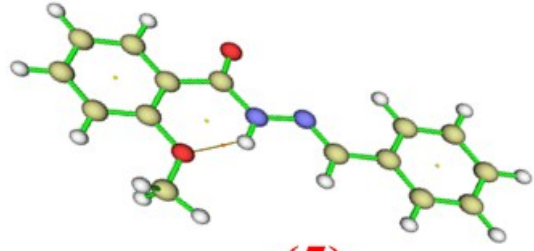

(5)

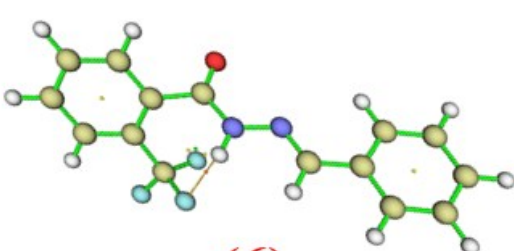

(6) 
b)<smiles>[Y]c1ccccc1C(=O)N/N=C/c1ccccc1</smiles>

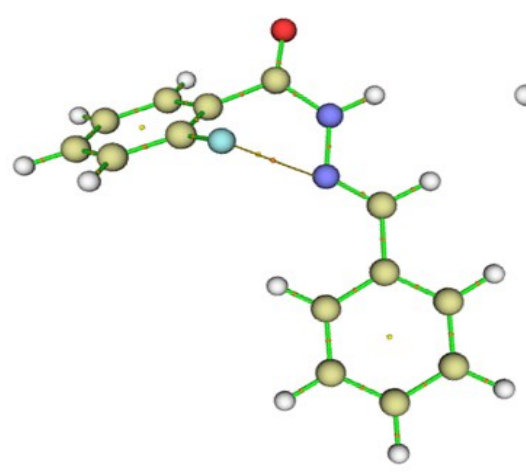

(2)

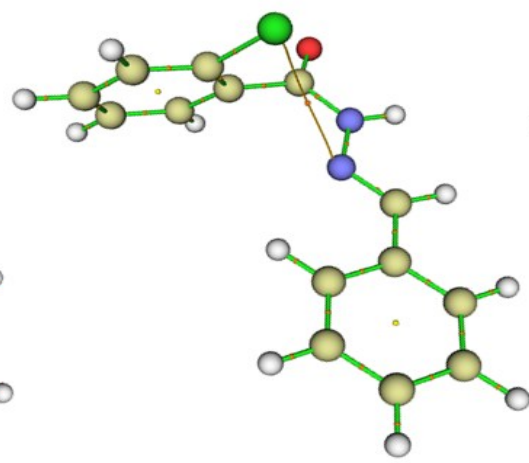

(3)

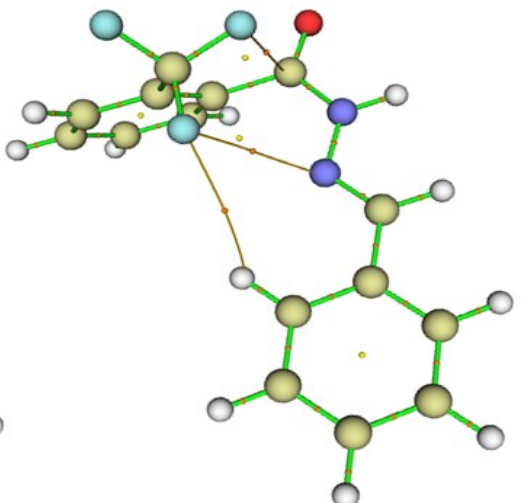

(6)

Figure S22. BCPs and bond paths a) for conformer I (trans, $\left.E_{\mathrm{C}-\mathrm{N}}\right)$ of molecules 1, 2, 3, 5 and 6; b) for conformer II $\left(c i s, E_{\mathrm{C}-\mathrm{N}}\right)$ of molecules $\mathbf{2}, \mathbf{3}$ and $\mathbf{6}$. Red dots indicate bond critical points and solid red line indicate the intramolecular HB.

Table S1. Values of Electron Density $\left(\rho_{(\mathrm{r})}\right)$ and Laplacian of Electron Density $\left(\Delta^{2} \rho_{(\mathrm{r})}\right)$ at $(3,-1)$ BCPs of $(\mathrm{X} \cdots \mathrm{HN}) \mathrm{HBs}$ for conformer I of molecules 2, 3, 5 and $\mathbf{6}$.

\begin{tabular}{|c|c|c|c|}
\hline Compound & $\begin{array}{c}\text { HB type } \\
(\mathbf{X}---H N)\end{array}$ & $\begin{array}{c}\text { Electron Density } \\
\left(\boldsymbol{\rho}_{(\mathrm{r})}\right)(\mathbf{a u})\end{array}$ & $\begin{array}{c}\text { Laplacian of electron } \\
\text { density }\left(\boldsymbol{\Delta}^{\mathbf{2}} \boldsymbol{\rho}_{(\mathrm{r})}\right)\end{array}$ \\
\hline 2 & $(\mathrm{~F}---\mathrm{HN})$ & 0.0153 & $\mathbf{I}$ \\
\hline 3 & $(\mathrm{Cl}---\mathrm{HN})$ & 0.0113 & 0.0966 \\
\hline 5 & $(\mathrm{MeO}---\mathrm{HN})$ & 0.0319 & 0.0435 \\
\hline 6 & $\left(\mathrm{CF}_{3}--\mathrm{HN}\right)$ & 0.0137 & 0.0522 \\
\hline
\end{tabular}




\section{NCI studies}

Non-covalent interactions ( $\mathrm{NCI}$ ) studies ${ }^{5}$ based on the electron density and its derivatives are used as a visualisation tool for the identification of non-covalent interactions. The identification is done on the basis of the peaks that appear in the reduced density gradient (RDG) at low densities. The electron density $\left(\rho_{(\mathrm{r})}\right)$ and the weak interaction forces show strong correlation giving negative and positive $\rho_{(\mathrm{r})}$ values for $\mathrm{HBs}$ and steric effects respectively. Whereas $\rho_{(\mathrm{r})}$ values for van der Waals interactions are very small (near to zero). ${ }^{6}$ Grid points were calculated using the multiwfn program $^{7}$ and plotted for two functions, $\operatorname{sign}\left(\lambda_{(\mathrm{r})}\right) \rho_{(\mathrm{r})}$, as function 1 and reduced density gradient (RDG) as function 2 (Fig. S23).

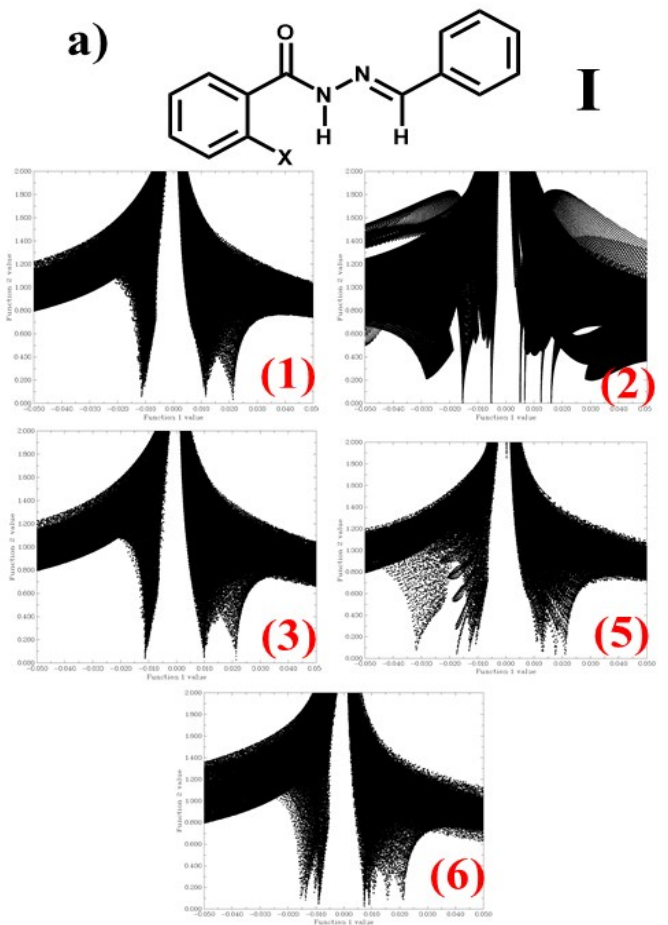

b)
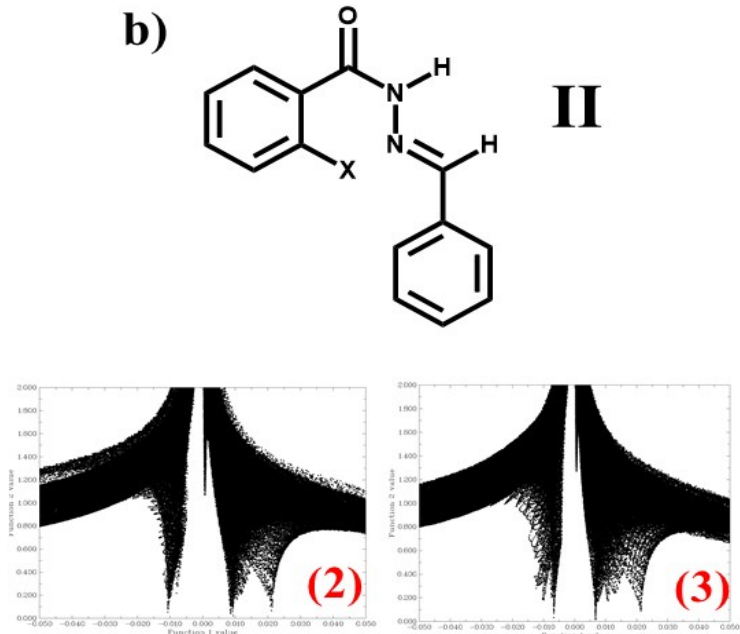

(3)

Figure S23. Plot of $\operatorname{sign}\left(\lambda_{(\mathrm{r})}\right) \rho_{(\mathrm{r})}$, as function 1 on $\mathrm{X}$-axis and reduced density gradient (RDG) as function 2 on Y-axis a) for conformer I (trans, $E_{\mathrm{C}-\mathrm{N}}$ ) of molecules $\mathbf{1 , 2}, \mathbf{3}, \mathbf{5}$ and $\mathbf{6}$; b) for conformer II (cis, $E_{\mathrm{C}-\mathrm{N}}$ ) of molecules $\mathbf{2}, \mathbf{3}$ and $\mathbf{6}$. 
From the same grid points, colour-filled isosurfaces were also plotted for clear visualization of different type of interactions using VMD program ${ }^{8}$ (Fig. S24). All the HBs are visualised as the green coloured isosurfaces whereas the red colour accounts for the steric hinderance due to phenyl rings and other HB mediated rings (Fig. S24).

a)<smiles>[X]c1ccccc1C(=O)N(C)/N=C/c1ccccc1</smiles>

I trans, $E_{\mathrm{C}-\mathrm{N}}$
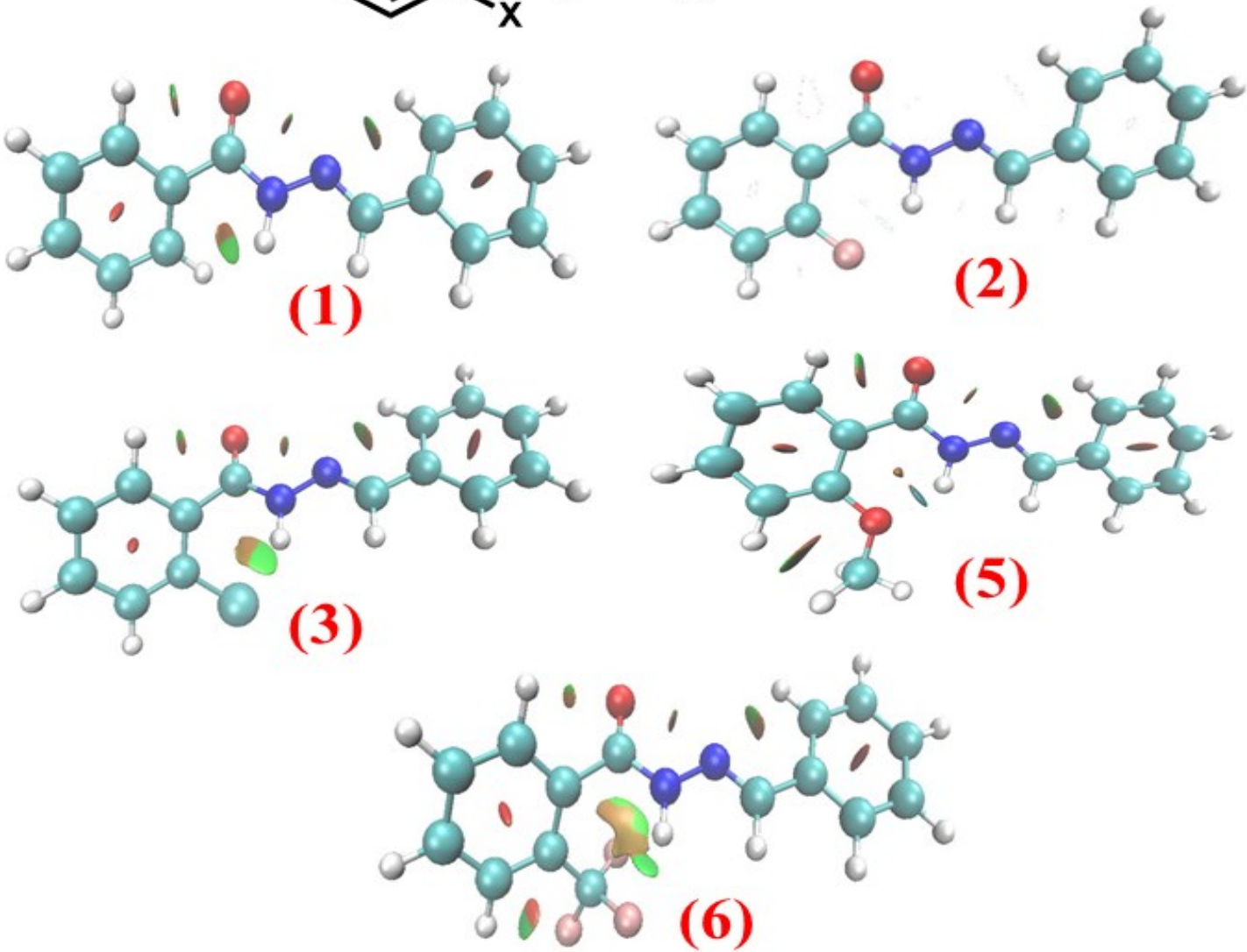
b)

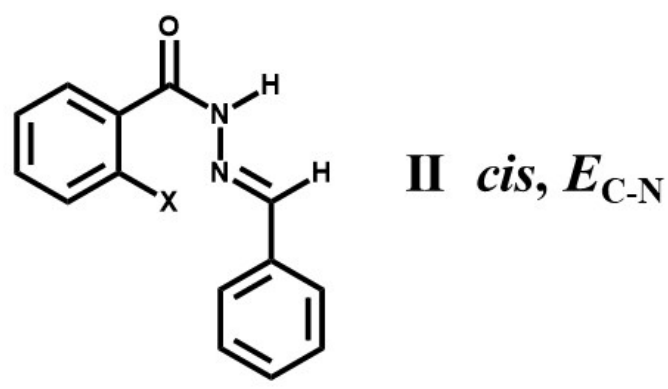

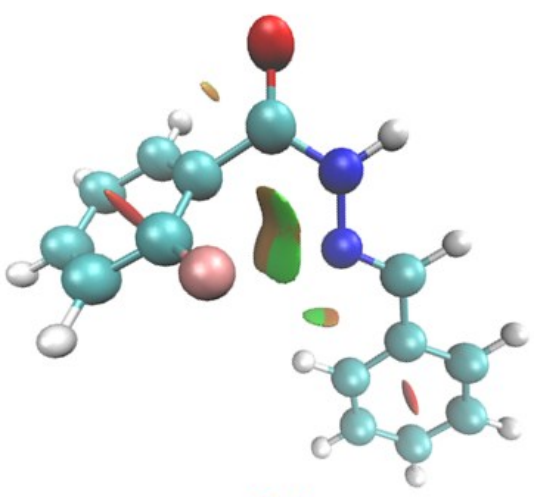

(2)

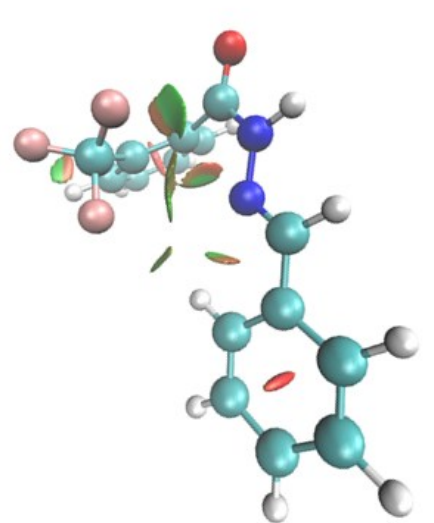

(3)

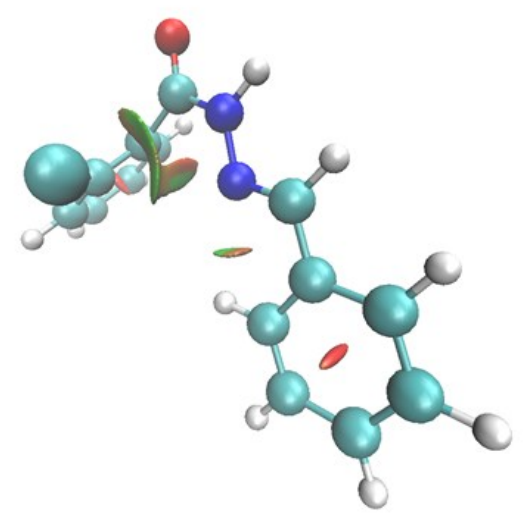

(6)

Figure S24. Coloured isosurface plots a) for conformer I (trans, $\left.E_{\mathrm{C}-\mathrm{N}}\right)$ of molecules 1, 2, 3, 5 and 6; b) for conformer II (cis, $\left.E_{\mathrm{C}-\mathrm{N}}\right)$ of molecules $\mathbf{2}, \mathbf{3}$ and 6. Green colour stands for HB and red colour denotes steric hindrance. 


\section{Experimental}

All the NMR spectra were acquired on 400 and $800 \mathrm{MHz}$ NMR spectrometers. TMS (tetramethylsilane) was used as the internal reference for both ${ }^{1} \mathrm{H}$ and ${ }^{13} \mathrm{C}$ NMR spectra. Deuterated $\mathrm{CDCl}_{3}$ and DMSO- $\mathrm{d}_{6}$ solvents were purchased and used as received. The characterization of all the synthesized molecules (1-6) was done by using various NMR experiments and ESI-MS technique. The available pulse programs in the library of NMR spectrometers were used for acquiring all the two-dimensional spectra, such as HSQC, NOSEY, COSY. Except for the temperature variation studies all other experiments were carried out at ambient temperature (298 K).

\section{Synthesis procedure of N'-Benzylidenebenzohydrazide}

Benzaldehyde and all the benzohydrazide derivatives were purchased and used as received. The X substituted benzohydrazide (1eq) was dissolved in chloroform and to it benzaldehyde ( 1 eq) was added drop by drop while stirring at $0^{\circ} \mathrm{C}$. The mixture was kept on stirrer for 5-6 hours. The solvent $\mathrm{CHCl}_{3}$ was evaporated using rotatory evaporator at a temperature and pressure of $50^{\circ} \mathrm{C}$ and $500 \mathrm{~mm} \mathrm{Hg}$ respectively. The white crude molecule left in RB was dissolved in $5 \mathrm{ml}$ chloroform and was kept overnight for crystallization with addition of 0.1 $\mathrm{ml}$ of methanol.

\section{ESI MS, Melting Point and Elemental Analysis}

The melting point for all the studied molecules was measured for 3 different samples and the obtained range is reported.

\section{Molecule 1:}

ESI-MS [M+H] ${ }^{+}$: Calculated for $\mathrm{C}_{14} \mathrm{H}_{12} \mathrm{~N}_{2} \mathrm{O} 224.10$ and found 224.10

Melting Point: $206-208^{\circ} \mathrm{C}$.

Elemental Analysis: Calculated (\%) for $\mathrm{C}_{14} \mathrm{H}_{12} \mathrm{~N}_{2}$ : C 74.98, H 5.39, N 12.49; found C 74.99, H 5.16, N 12.20

\section{Molecule 2:}

ESI-MS [M+H] $]^{+}$: Calculated for $\mathrm{C}_{14} \mathrm{H}_{11} \mathrm{FN}_{2} \mathrm{O} 243.09$ and found 243.09 
Melting Point: $125-126^{\circ} \mathrm{C}$.

Elemental Analysis: Calculated (\%) for $\mathrm{C}_{14} \mathrm{H}_{11} \mathrm{~N}_{2}$ : C 69.41, H 4.58, N 11.56; found C 69.28, H 4.36, N 11.51

\section{Molecule 3:}

ESI-MS $[\mathbf{M}+\mathbf{H}]^{+}:$Calculated for $\mathrm{C}_{14} \mathrm{H}_{11} \mathrm{ClN}_{2} \mathrm{O}[\mathrm{M}+\mathrm{H}]+259.06$ and found 259.06

Melting Point: $165-167^{\circ} \mathrm{C}$.

Elemental Analysis: Calculated (\%) for $\mathrm{C}_{14} \mathrm{H}_{11} \mathrm{~N}_{2}$ : C 65.00, H 4.29, N 10.83; found C 65.19, H 4.08, N 10.99

\section{Molecule 4:}

ESI-MS [M+H] $]^{+}$: Calculated for $\mathrm{C}_{14} \mathrm{H}_{12} \mathrm{~N}_{2} \mathrm{O}_{2} 241.09$ and found 241.09

Melting Point: $232-235^{\circ} \mathrm{C}$.

Elemental Analysis: Calculated (\%) for $\mathrm{C}_{14} \mathrm{H}_{12} \mathrm{~N}_{2}$ : C 69.99, H 5.03, N 11.66; found C 69.78, H 5.08, N 11.41

\section{Molecule 5:}

ESI-MS [M+H] $]^{+}$: Calculated for $\mathrm{C}_{15} \mathrm{H}_{14} \mathrm{~N}_{2} \mathrm{O}_{2} 255.11$ and found 255.11

Melting Point: $180-182^{\circ} \mathrm{C}$.

Elemental Analysis: Calculated (\%) for $\mathrm{C}_{15} \mathrm{H}_{14} \mathrm{~N}_{2}$ : C 70.85, H 5.55, N 11.02; found C 70.37, H 5.38, N 10.94

\section{Molecule 6:}

ESI-MS [M+H] $]^{+}$: Calculated for $\mathrm{C}_{15} \mathrm{H}_{11} \mathrm{~F}_{3} \mathrm{~N}_{2} \mathrm{O} 293.09$ and found 293.09

Melting Point: $158-159^{\circ} \mathrm{C}$.

Elemental Analysis: Calculated (\%) for $\mathrm{C}_{15} \mathrm{H}_{11} \mathrm{~N}_{2}$ : C 61.65, H 3.79, N 9.59; found C 61.28, H 3.57, N 9.35 


\section{References}

1. W. Kohn and L. J. Sham, Phys. Rev., 1965, 140, A1133.

2. R. G. Parr and W. Yang, Density-Functional Theory of Atoms and Molecules, Oxford University Press, New York, 1989.

3. R. F. W. Bader, Atoms in Molecules: A Quantum Theory, Oxford University Press, Oxford, 1990.

4. N. S. Golubev, I. G. Shenderovich, S. N. Smirnov, G. S. Denisov and H.-H. Limbach, Chem. Eur. J., 1999, 5, 492.

5. R. F. W. Bader, S. G. Anderson and A. J. Duke, J. Am. Chem. Soc., 1979, 101, 1389-1395.

6. E. R. Johnson, S. Keinan, P. Mori-Sánchez, J. Contreras-García, A. J. Cohen and W. Yang, J. Am. Chem. Soc., 2010, 132, 6498-6506.

7. T. Lu and F. Chen, J. Comput. Chem., 2012, 33, 580-592.

8. W. Humphrey, A. Dalke and K. Schulten, J. Mol. Graphics, 1996, 14, 33-38. 